\title{
Piedmont deposits as seismic energy dissipators, Sierras Pampeanas of Argentina
}

\author{
Adolfo Antonio Gutiérrez ${ }^{1}\left[\right.$ D Ricardo Mon ${ }^{1,2} \cdot$ Ahmad Arnous $^{1,2} \cdot$ Rodolfo Germán Aranda-Viana $^{1,2}$
}

Received: 24 July 2021 / Accepted: 11 November 2021

Published online: 25 November 2021

(c) The Author(s) $2021 \quad$ OPEN

\begin{abstract}
This study shows the neotectonic deformation occurred in the southern piedmont of the Cumbres Calchaquíes, in the Amaicha and Tafí valleys. Neotectonic deformation manifests itself through faults, folds and diversions of drainage channels. The Amaicha valley is bounded to the north by the Tafí del Valle fault and to the south by the Los Cardones fault. The Cumbres Calchaquíes ride over the Sierra de Aconquija through the Los Cardones and Carapunco faults. The Carapunco fault also has a synestral component, responsible for generating an imbricated system of contractional fractures. In the study region many earthquakes of $\geq 3$ and $\geq 4$ magnitude coincide with regional faults evidencing its neotectonic activity. The seismic energy dissipated through materials with less cohesion that form the fill of the valleys, generating discrete fault scarps and strongly folded conglomerate strata. The foothills deposits of the Cumbres Calchaquíes absorbed most of the seismic energy released during the reactivation of the faults. Tectonic activity is deforming 630 a BP deposits in the Cumbres Calchaquíes piedmont.
\end{abstract}

Keyword Neotectonics · Andes · Sierras Pampeanas · Earthquakes $\cdot$ Natural hazards

\section{Introduction}

The deformation of the Andean foreland by neotectonic processes has been treated extensively in the national and international literature. This evidences the interest of the scientific community in understanding tectonic rotations, direction of tectonic shortening, depths of detachment of the main structures, position of the front deformation, vergence of the structures, seismic activity associated with the movements of the faults and deformations of the mountain fronts.

The Tafí and Amaicha valleys are intramontane tectonic basins located in the province of Tucumán, Argentina, in the northern end of the Sierras Pampeanas (Fig. 1). The
Tafí valley is located in the northeast end of the Sierra de Aconquija, bordered to the north by the Cumbres Calchaquíes. In the center of the valley, the independent relief of Loma Pelada stands out, dividing the valley into two related areas, Las Carreras valley to the west and Tafí valley itself to the east (Fig. 2). The bottom of the Tafi Valley is between 1800 and 2300 ma.s.l., crossed from north to south by the Tafí del Valle river. The Amaicha valley, with NW strike, extends to the northwest of the Tafí valley, from the Infiernillo pass to the Santa María valley, limited to the north by the Cumbres Calchaquíes and to the south by the Sierra de Aconquija (Figs. 1, 2).

Studies carried out in the Tafí and Amaicha valleys have not addressed the valley's tectonics. Until now,

$\triangle$ Adolfo Antonio Gutiérrez, gutierrez.aa@hotmail.com; Ricardo Mon, ricardomon@arnet.com.ar; Ahmad Arnous, aarnous.aa@gmail.com; Rodolfo Germán Aranda-Viana, german.aranda.gn20@gmail.com | ${ }^{1}$ Facultad de Ciencias Naturales e IML, Universidad Nacional de Tucumán, Miguel Lillo 205, 4000 San Miguel de Tucumán, Argentina. ${ }^{2}$ CONICET (Concejo Nacional de Ciencia y Técnica), Buenos Aires, Argentina.

SN Applied Sciences $\quad$ (2021) 3:887 $\quad$ https://doi.org/10.1007/s42452-021-04874-0 


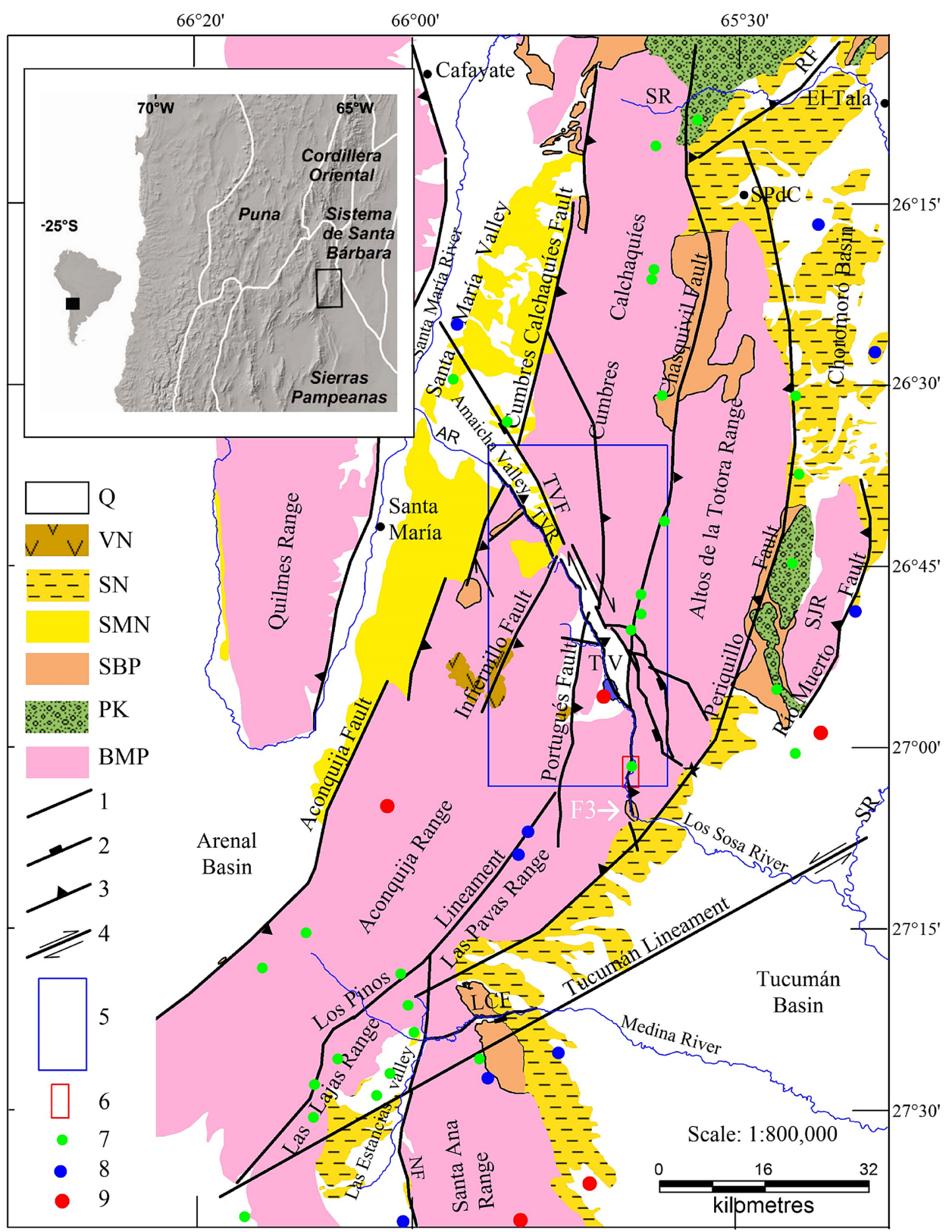

Fig. 1 Regional location of the study area. Morphotectonic map to show the major orographic units and the regional structures that limit them. Q: Fluvio-eolian deposits, Quaternary. VN: Volcanic rocks, Neogene. SN: Neogenic sediments of the Tucumán basin and the Choromoro valley. SMN: Santa María Group, Neogene. SBP: Santa Bárbara Subgroup, Salta Group, Paleogene. PK: Pirgua Subgroup, Salta Group, Cretaceous. BMP: Proterozoic early - Paleo- zoic Basement. 1: Lineaments. 2: Normal Fault. 3: Reverse Fault. 4: Transcurrent Fault. 5: Study area. 6: Fig. 4 location. 7: Seism $M \geq 3$. 8: Seism $M \geq 4$. 9: Seism $M \geq 5$. SPdC: San Pedro de Colalao. AR: Amaicha River. RF: Rearte Fault. TVF: Tafí del Valle Fault. TV: Tafi Valley. SJR: San Javier Range. LCF: Las Cañas Fault. SR: Salí River. NF: Narváez Fault. F3: Fig. 3 location 
Fig. 2 Morphotectonic map of the Tafí and Amaicha valleys. It shows the depressions of Tafí and Amaicha and the regional structures that gave rise to them. In addition, they do indicate the larger geological units that condition the fracturing that gave rise to the valleys. On this scheme, the recently generated structures that are deforming the foothills were drawn with red lines. Q: Fluvioeolian deposits, Quaternary. YN: Yasyamayo Formation, Neogene. VN: Volcanic rocks, Neogene. LCN: Los Corrales Formation, Neogene. AN: Andalhuala Formation, Neogene. SP: Saladillo Formation, Paleogene. GrPz: Paleozoic granites. BMP: Proterozoic early - Paleozoic Basement. 1: Lineaments. 2: Normal Fault. 3: Reverse Fault. 4: Transcurrent Fault. 5: Recent structures. 6: Bedding with dip indication. AF: Aconquija Fault. LCF: Los Corpitos Fault. LAD: La Angostura Dam. OF: Ovejería Fault. PR: Pelado River. AA': Profile Fig. 5. BB': Profile Fig. 8. CC' Profile Fig. 9. F7: Fig. 7 location. F3b: Fig. 3b location

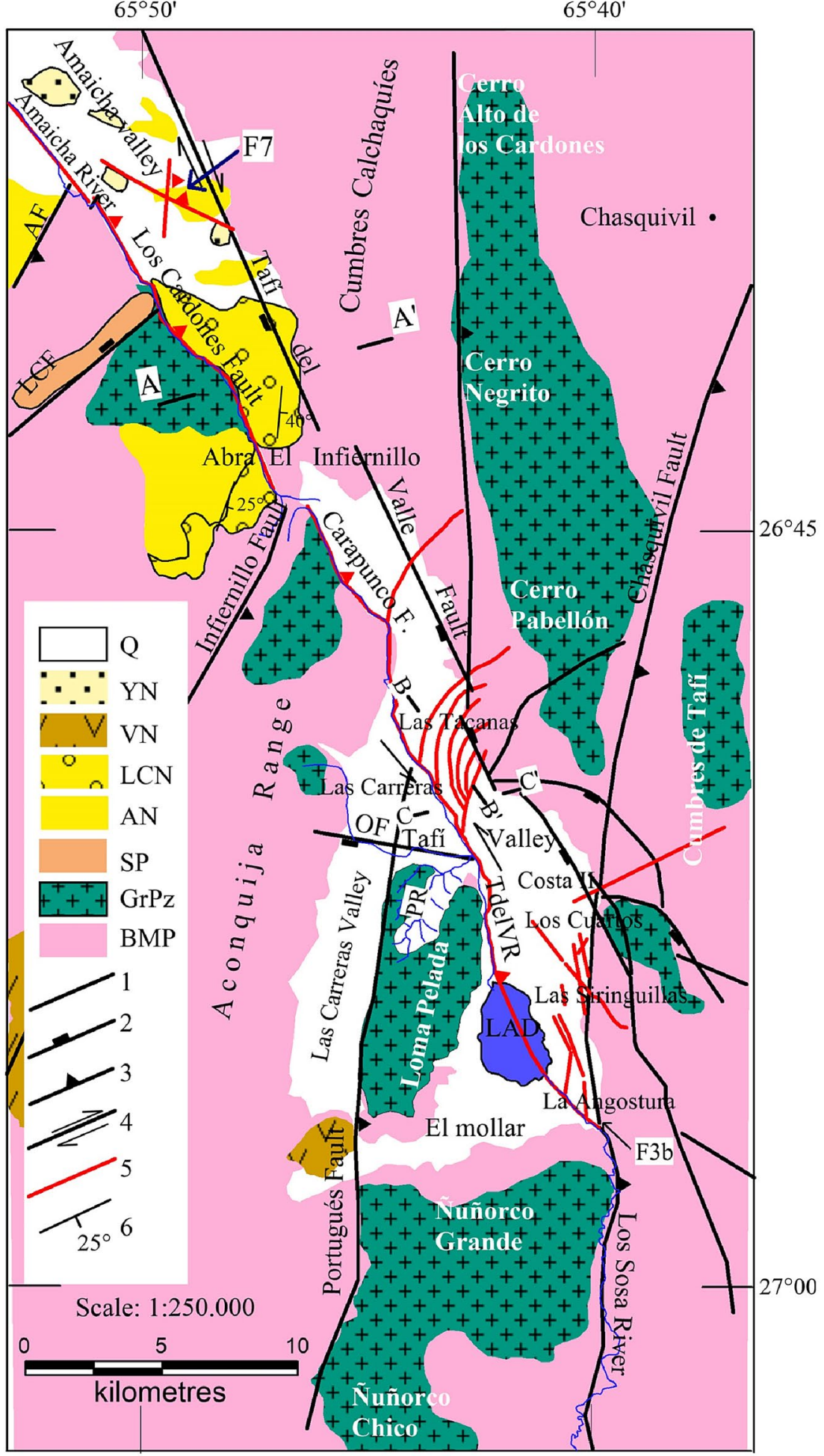

no faults or folds had been recorded in these valleys. Even the geomorphological studies did not deal in detail with the landscape deformation, deviation of the drainage channels, backward erosion, seismic activity, topographic unevenness of the foothills, etc.
So far there is no agreement on regional faults in the Amaicha valley. Ruiz Huidobro [1], Ferreiro and Mon [2], González [3] and González and Barreñada [4] considered that the Amaicha depression was delimited by fault on both edges. With another interpretation, Gutiérrez et al. [5], 
Gutiérrez and Mon [6] and Mon et al. [7] considered that only the Tafí del Valle fault separated the Cumbres Calchaquíes from the Sierra de Aconquija, with a normal component sloping to the SW and another dextral horizontal slip. The Tafí del Valle fault [8] would have disposed the Cumbres Calchaquíes on the Sierra de Aconquija [4]. The classic scheme proposed by González Bonorino [9] considers that the basement blocks were raised by large lystric reverse faults.

Our work shows the differential deformation in a mountain front as a result of the propagation of seismic energy through foothills deposits. In this analysis, the cohesion of the geological material is considered relevant for the propagation of the seismic energy produced by the activity of the faults. We take as a study case the neotectonic activity in the Tafí and Amaicha valleys and the structural relationship between the Cumbres Calchaquíes and Sierra de Aconquija. We show the structures and morphologies generated in the southern foothills of the Cumbres Calchaquíes. These structures with vertical and horizontal components occur in foothills, close to regional structures on the mountain front. Previous theories related to the existence or not of two faults in the Amaicha valley are also discussed and field data are presented.

\section{Methodology}

The research was carried out based on the collection of bibliographic antecedents, interpretation of satellite images and field data surveys. To develop thematic cartography, the visual and digital interpretation of satellite images LANDSAT 8, SENTINEL 1, RADARSAT were carried out. The digital treatment for the visual interpretation of the LANDSAT and SENTINEL images consisted of the combination of different bands. All satellite and radar images were interpreted using the QGis software and then thematic maps were drawn. To prepare the topographic profiles we used high resolution digital elevation models $(12.5 \mathrm{~m})$ provided by the ALOS PALSAR mission. During field work, the surfaces deformed by neotectonic processes were identified (fault steps, landslide zones, deformed foothills, whale-back morphologies in alluvial fans, erosion of conglomerate terraces and transport of rolling by surface drainage, development of drainage networks as indicators of deformation) and data on the structures that generated these morphologies were collected.

\section{Regional tectonic morphology}

In the plate tectonics context, subjected to compressive stress with NE strike during the Cenozoic, the study area coincides with the latitude where the Nazca plates change the angle dip, high angle north of $27^{\circ} \mathrm{S}$ and low angle at south [10-12].

SN Applied Sciences

\subsection{Morphology}

The Sierra de Aconquija and Cumbres Calchaquíes seem to have formed a single mountain block with a NNE strike and slightly curved, concave towards the west. It have been raised by high-angle, double vergent, reverse faults on both edges $[13,14]$, Cumbres Calchaquíes and Aconquija faults on the western edge and Periquillo fault on the eastern edge (Fig. 1).

Probably in the Pleistocene the drainage system developed on the eastern edge of the Cumbres Calchaquíes, Sierra de Aconquija and Ambato block had an approximate general direction towards the east and ended in the Chaco plain, covering a large area of surface runoff, maintaining the contribution of coarse sediments by the continuous uplift of the mountain system and appropriate climatic conditions [5]. The records of these hydrogeological processes are the thick conglomerates deposits arranged in the upper parts of the terraces of the Los Sosa River, which were eroded by the current surface runoff. Later, with the progress of tectonic activity, this drainage system completely eroded, configuring the current network [5]. The Tafí valley is independent from the Amaicha valley, the water sub-basins of both valleys have their springs in the Infiernillo pass (Figs. 1, 2). The waters of the Amaicha valley are part of the Plata basin through the Santa María, Las Conchas and Salado rivers, and the waters of the Tafí valley end in the Salí - Dulce river, forming part of the endorheic basin of the Mar Chiquita lagoon [15-17].

\subsection{Regional geology}

These ranges are made up of an igneous - metamorphic basement (Upper Proterozoic — Lower Paleozoic) $[18,19]$ (Fig. 1). Sediments from the Cretaceous Rift could not have covered these mountain ranges because they were elevated [7], the outcrops of the Pirgua Subgroup of the Salta Group reached the northern end of the Cumbres Calchaquíes and the western edge of the Sierra de San Javier (Fig. 1).

Neogene sediments occupied the Choromoro and Las Estancias basins in Tucumán and the Santa María basin in Catamarca. In the Santa María valley the sedimentary sequence overlaps the metamorphic basement towards the Amaicha valley, reaching the Infiernillo pass $[7,20,21]$, while in the northern end from the Sierra de Aconquija the volcanism that gave rise to the extrusive rocks of Cerro Las Ánimas occurred ca. $13 \mathrm{Ma}[22,23]$. The sedimentary column of the Santa María valley was ordered in Sequences by Bossi et al. [15] (Table 1).

In the Tafí valley, on the igneous-metamorphic basement [32] rest thick grayish-brown conglomerates, called Lomitas Pegadas Formation [33], covered by loess from Tafí 
Table 1 Stratigraphic sequence of the Santa María Group according to Bossi et al. [15]. Dating made by Powell and González [24], Spagnuolo et al. [25], Georgieff and Díaz [26], Butler et al. [27], Marshall and Patterson [28], Strecker et al. [29]. Identification of quaternary morphosedimentary units by Peña Monné and Sampietro Vattuone [30] and Sampietro Vattuone et al. [31]. Q: Quaternary.

\begin{tabular}{|c|c|c|c|c|c|c|c|}
\hline ERA & \multicolumn{2}{|c|}{ Period/Epoch } & Ma & \multicolumn{4}{|c|}{ Stratigraphy } \\
\hline \multirow{10}{*}{ 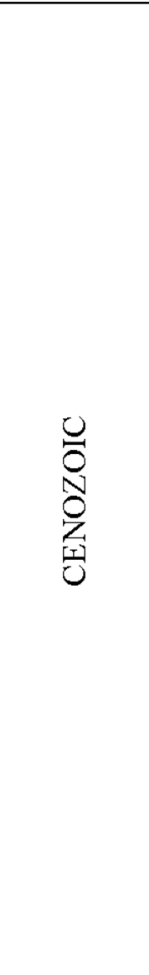 } & \multirow{3}{*}{$\mathrm{Q}$} & Holocene & \multirow{3}{*}{$\begin{array}{l}0.00006 \\
0.0004 \\
0.0013 \\
\\
1.15\end{array}$} & \multirow{2}{*}{\multicolumn{4}{|c|}{$\begin{array}{l}\mathrm{H} 2 \\
\mathrm{H} 1\end{array}$}} \\
\hline & & & & & & & \\
\hline & & Pleistocene & & \multicolumn{4}{|c|}{$\begin{array}{l}\text { Tafí del Valle Formation } \\
\text { Lomitas Pegadas Formation }\end{array}$} \\
\hline & \multirow{4}{*}{ 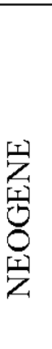 } & \multirow{2}{*}{ Pliocene } & \multirow{4}{*}{$\begin{array}{l}2.5 \\
3.4 \\
4.0 \\
6.02 \\
6.7 \\
6.88 \\
9.1\end{array}$} & \multirow{4}{*}{ 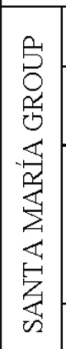 } & Sequence IV & \multirow{3}{*}{ 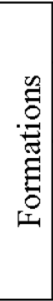 } & Yasyamayo \\
\hline & & & & & Sequence III & & $\begin{array}{l}\text { Los Corrales } \\
\text { Upper Andalhuala }\end{array}$ \\
\hline & & \multirow[t]{2}{*}{ Miocene } & & & Sequence II & & $\begin{array}{l}\text { Lower Andalhuala } \\
\text { Chiquimil } \\
\text { Las Arcas } \\
\text { San José } \\
\end{array}$ \\
\hline & & & & & & \multicolumn{2}{|c|}{ Paranense } \\
\hline & \multirow{3}{*}{ 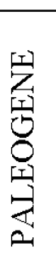 } & Oligocene & & & & & \\
\hline & & Eocene & \multirow{3}{*}{16} & & Sequence I & \multicolumn{2}{|c|}{ Saladillo Formation } \\
\hline & & Paleocene & & \multicolumn{4}{|c|}{ SANTA BÁRBARA GROUP } \\
\hline $\begin{array}{l}\text { Paleozoic - } \\
\text { Proterozoic } \\
\text { early }\end{array}$ & & & & \multicolumn{4}{|c|}{ Basement } \\
\hline
\end{tabular}

del Valle Formation [34], dated at 1.15 Ma (Middle Pleistocene) by Schellenberger et al. [35] (Table 1).

Organic matter contained in lake sediments in the area of El Rincón, Tafí del Valle, were dated with ${ }^{14} \mathrm{C}$, registering ages between 10,350 \pm 80 and $4120 \pm 60$ a BP [36]. Ortíz and Jayat [37] carried out radiocarbon dating on bone remains found in the Tafí del Valle Formation and located it at the Pleistocene-Holocene limit (10.25-9.65 ka cal. BP). Recent studies carried out an evolutionary geomorphological model of the Lateglacial and Holocene accumulations in the valleys determining four degradation stages dated between 13,000 and 630 a BP with ${ }^{14} \mathrm{C}$, thermo Luminiscence and tephra layers underlying charcoal samples [30, 31, 38] (Table 1).

\subsection{Regional structures}

Marrett et al. [39] document for northwestern Argentina two kinematic regimes that characterize the late Cenozoic deformation, a WNW shortening and a strike-slip phase with ENE shortening. Riller and Oncken [40] consider that the segmentation of the upper crust into rhomb-shaped domains confined by transpressive ranges resulted from the decrease in crustal shortening with distance to the central bend of the Andes and Strecker et al. [41] and Mon [42] agree that the faults that raise the edges of the mountain ranges could be reactivated Paleozoic structures. Currently, the Sierra de Aconquija-Cumbres Calchaquíes mountain range is separated at the western edge where it opens towards the Santa María valley through the Amaicha valley (Fig. 1). On the eastern edge it remains together, but both mountains are unlinked by the Tafí del Valle fault (Fig. 1).

The Tafí del Valle fault zone has evidence of variations along strike proved by the interpretation of satellite images, surface geometry and the rock outcrops in the Tafí and Amaicha valleys. In the southeastern end it is a single plane that separates the Sierra de Aconquija from the Cumbres Calchaquíes. It was possible to measure the fault plane in a stream, at the entrance to the Tafí valley, registering the following values $\left(225^{\circ} / 88^{\circ}, 228^{\circ} / 85^{\circ}\right)$ (Figs. $2,3 \mathrm{a}$ ). In the north end of the Tafí valley, at the foot of the fault, a wide deposit of piedmont develops that reaches $23 \mathrm{~km}$ in length and extends between 2 and $4 \mathrm{~km}$ in width. It is assumed that these deposits are arranged on a metamorphic basement hiding the fault plane (Fig. 2). In the 

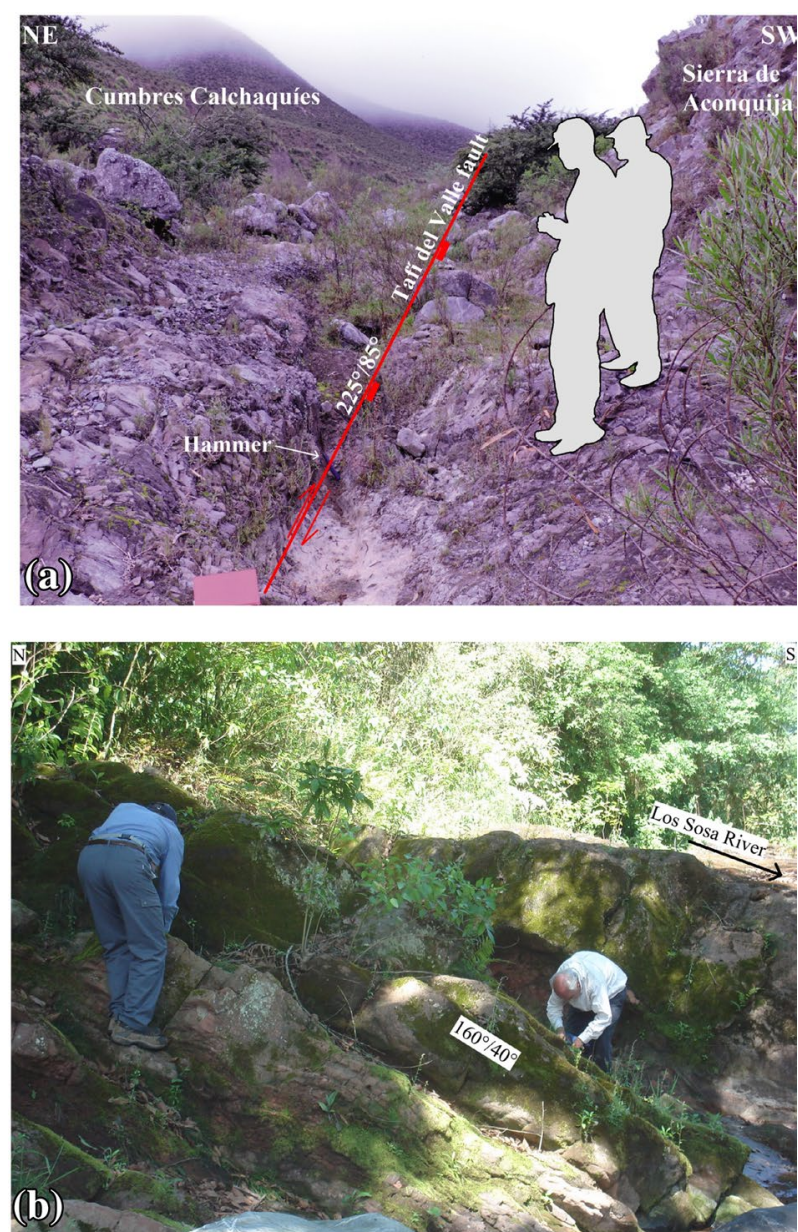

Fig. 3 a View of the Tafí del Valle fault with normal and dextral transcurrent displacement components. The hammer indicates the fault plane, high angle. It marks the limit between the Sierra de Aconquija and the Cumbres Calchaquíes. b Reduced outcrop of sandstones and conglomerate siltstones of the Santa Bárbara Subgroup, Salta Group, on both banks of the Los Sosa River, southern end of the Chasquivil fault. The sedimentary strata dips to the southeast $\left(160^{\circ} / 40^{\circ}\right)$ tilted by the Chasquivil fault. The location of the photo can be seen in Fig. 1

Amaicha valley, the fault zone is about $6 \mathrm{~km}$ wide, hosts the upper sequence of the Santa María Group and opens towards the Santa María valley, where the dextral transcurrent geometry of the fault was verified [7] (Fig. 2).

Internally, the mountainous ensemble is also cut by regional NNE structures (Infiernillo, Portugués, Chasquivil faults and Los Pinos lineament), which do not manage to completely separate them, but give the ensemble a morphology that allows identifying minor mountain ranges such as Las Lajas, Las Pavas and Altos de la Totora, which, had the initial deformation continued, would have formed independent units, as is the case with the San Javier range (Fig. 1). In some cases, these structures gave rise to important rivers such as the Amaicha, Tafí del Valle-Los Sosa and Las Cañas rivers and, other times, they separate mountain blocks, such as the Los Pinos lineament that separates the Las Lajas and Santa Ana mountains from the Sierra de Aconquija (Fig. 1).

The central zone of the Cumbres Calchaquies and northern end of the Sierra de Aconquija, crossed by the NNE structures, the Portuguese fault (to the west) and the Chasquivil fault (to the east), is intruded by granite bodies that constitute a strip with the same orientation as structures that limit them, where the Alto de los Cóndores, Negro, Pabellón, Loma Pelada, Ñuñorco Grande and Ñuñorco Chico hills stand out (Fig. 2).

A cortical extension was postulated in the early Miocene to explain the origin of Cenozoic basins in the northwestern Sierras Pampeanas that were inverted at approximately $5 \mathrm{Ma}[1,6,15]$. However, it is likely that these regional structures were partially active during the Cretaceous Rift, but did not evolve sufficiently to form depocenters. For example, the Sierra de Aconquija and Cumbres Calchaquíes remained elevated during the Cretaceous because no outcrops of this age were found in the inner valleys [7]. But, in all these regional NNE structures spaces were generated during the Cretaceous Rift where small outcrops of red sandstones and conglomerate siltstones are preserved, attributed to the Santa Bárbara Subgroup of the Salta Group (Paleogene) (Fig. 1). We can see them along the Aconquija and Cumbres Calchaquíes faults, in the Los Corpitos fault, on the eastern edge of the Los Pinos lineament and on the eastern slope of the Santa Ana mountain range, on the northeastern edge and southern end of the Chasquivil fault, in the Los Sosa riverbed and on the eastern edge of the Periquillo fault (Figs. 1, 2, $3 b)$. These reduced outcrops of red strata attributed to the Santa Bárbara Subgroup and arranged on a metamorphic basement document that the other lower sequences of the Salta Group are not found in these regional structures. Possibly, in the Cretaceous Rift stage, the Aconquija, Cumbres Calchaquíes, Los Corpitos, Infiernillo and Portugués faults constituted incipient steps that dipped towards the west, just as the Chasquivil fault represented a step dipping to the east, and the mountainous group remained elevated (Figs. 1, 2). The granite bodies represented by the Alto de los Cardones, Negrito, Pabellón, Loma Pelada, Ñuñorco Grande and Ñuñorco Chico hills constituted a longitudinal block towards which the steps of the normal faults converged, those that inclined to the east and those that inclined to the west (Fig. 2). In the lower Tertiary these small steps began to fill up with the sediments of the Santa Bárbara Subgroup and were protected in the elevated parts of the slopes of the mountains, such as on the western edge of the Sierra de Aconquija and Cumbres Calchaquíes, in the Los Corpitos fault. [7, 22], in the Chasquivil fault and many other places (Figs. 1, 2, 3b). Against

\section{SN Applied Sciences}


the Infiernillo fault, the upper sequence of the Santa María Group ends and filling the Amaicha valley, without reaching the Tafí valley [7].

These areas of regional weakness, Cretaceous or Paleozoic, were reactivated with the Andean tectonics. Sometimes the normal faults of the Cretaceous Rift were reactivated in the same direction as the initial fault plane, but in the opposite sense [43-46] and later on, these faults were cut by others with opposite sense and direction such as the Aconquija, Cumbres Calchaquíes, Infiernillo faults $[6,7,22,47]$. However, the Chasquivil fault would have had a reverse reactivation because it arranged the preserved red strata in the Los Sosa River dipping $40^{\circ}$ to the SE (Fig. 3b). Pilger [48] interpreted that the uplift of the marginal mountain ranges to the Calchaqui valley would have started at $13 \mathrm{Ma}$. Tectonic activity would have accelerated around $4 \mathrm{Ma}$, affecting the Yasyamayo Formation (ca. 1.5 Ma), therefore would have occurred at approximately 1.2 Ma, extending to at least 0.6 Ma [49] and the eastern edge of the Sierra de Aconquija began to rise at 9 Ma [50] (Fig. 2).

\section{Seismic record}

According to the seismic classification for Argentina, based on studies carried out until 1983, with the exception of the areas surrounding the cities of Salta and San Salvador de Jujuy, the north and a large part of the Sierras Pampeanas are located in Zone 2, of moderate danger [51]. We collect information on the seismicity around the study area, recording only earthquakes with magnitudes between 3 and 6 [52]. From 1973 to date there have been 31 earthquakes of magnitude $\geq 3$ registered between 7 and $204 \mathrm{~km}$ depth, 9 earthquakes of magnitude $\geq 4$ generated between 8 and $60 \mathrm{~km}$ depth and 5 earthquakes of magnitude $\geq 5$ between 27 and $37 \mathrm{~km}$ deep (Fig. 1). We observe that earthquakes of magnitude $\geq 3$ are aligned with regional structures such as the Tafí del Valle, Aconquija, Chasquivil, Periquillo, Las Cañas faults and the Los Pinos and Tucumán lineaments (Fig. 1). The earthquakes of magnitude $\geq 4$ are aligned with the Tucumán and Los Pinos lineaments and the Narváez and Río Muerto faults and two of the earthquakes of magnitude $\geq 5$ with the Río Muerto and Carapunco faults (Figs. 1, 2). Other recent and recurrent evidence of tectonic activity in the Tafí and Amaicha valleys and in the surrounding region are river captures [5], landslides and rock falls like on the left slope of the Los Sosa River (Fig. 4) on Provincial Route 307 (Fig. 2) and retrograde erosion.

\section{Earthquakes effects}

In the seismogenic region of the continental crust (15-18 km), earthquakes produce an episodic rigid frictional deformation [53-56] whose rupture by propagation during deformation is controlled by the anisotropic fabric at the cortical scale [57]. When an earthquake is generated, oscillations occur in existing faults or, less frequently, in new faults $[56,58]$, the elastic stress accumulating in the rocks surrounding the fault zone, until the resulting stress in the plane it exceeds its frictional resistance and failure occurs [59].

The conditions of the shear stress $\left(\tau_{f}\right)$ at which the failure is going to slip are indicated by the equation

$$
\tau f=C_{\circ}+\mu_{s}\left(\sigma_{n}-P_{f}\right)
$$

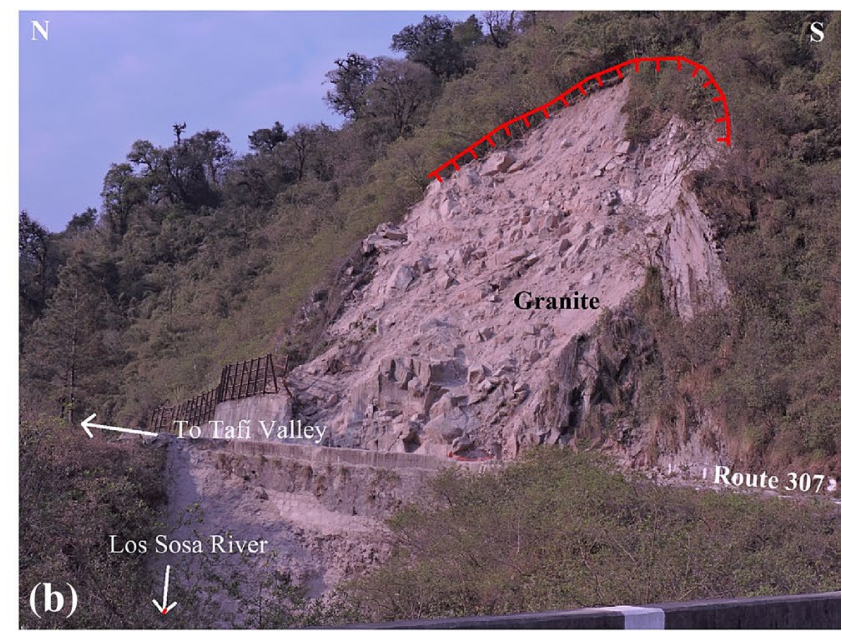

Fig. 4 a Azucena landslide on the left bank of the Los Sosa river (Chasquivil fault). b Fin del Mundo landslide on the left bank of the Los Sosa river (Chasquivil fault). Landslide scars are shown with red lines 
where $C_{o}$ is the cohesion force, $\mu_{s}$ is the coefficient of static friction, $\sigma_{n}$ is normal effort and $P_{f}$ is the fluid pressure [59] and high fluid pressures would favor the reactivation of faults, reducing the cohesion force [60]. However, for new faults to form in a region where faults already exist it is required that those old faults develop sufficient cohesion and/or have insufficient fluid pressure in the pores, in such a way as to prevent them from reactivating, even with favorable orientations [60]. It was also suggested that the migration of the fault activity towards the foothills is due to the cessation of activity of the faults of the mountain fronts, these new structures inheriting the style of the main faults [61]. Most earthquakes result from increased shear displacement in the fault [62] generating rupture and slip that are roughly related to the magnitude of the earthquake [63-65] (Table 2).

Different effects of seismic wave propagation are observed in the study area. Figure 4 shows the breakdown of granitic and metamorphic rocks in the plane of the Chasquivil fault due to the propagation of seismic waves during its reactivation. These crushed rocks, suspended on steep slopes, weather, form soils, rainwater saturates their pores and trigger landslides. New fractures were generated in the Amaicha and Tafí valleys and in the Tafí valley folds of the conglomerate strata were produced in the pedemontane deposits (Fig. 2).

\section{Quaternary deformations}

Numerous works document the recent tectonic activity in Geological Provinces of Argentina that occur in the foothills, in the intra- and intermontane basins or also refer to the geological processes triggered on the mountain fronts by active seismic activity, such as landslides in the slopes of the mountains, formation of dikes by obstruction of rivers, etc. The earthquake rupture zone is not located in the main fault zone of the mountain front but on the flank of the mountain range [66], in a new fault zone called FAF (frontal active fault/flexture) that it is generated due to the marked difference in stiffness between the piedmont and basement deposits $[61,67]$.

Table 2 Approximate source parameters for different magnitude earthquakes (partial magnitudes), with average stress drop (3 MPa) over a circular rupture $(\mathrm{L}=\mathrm{W})[59-63]$

\begin{tabular}{lll}
\hline Magnitude of Mw & Average slip (cm) & $\begin{array}{l}\text { Length } \\
(\mathrm{L})=\text { Width } \\
(\mathrm{W})\end{array}$ \\
\hline 5 & 10 & $3 \mathrm{~km}$ \\
4 & 3 & $1 \mathrm{~km}$ \\
3 & 1 & $30 \mathrm{~m}$ \\
\hline
\end{tabular}

On the southeastern edge of the Precordillera, the neogene strata ride on quaternary deposits of the foothills of the mountain front and, in the Sierra Chica de Córdoba, Sierras Pampeanas, the most recent deformations linked to the Sierra Chica fault system are not located in the topographic break of the mountain slope, but usually appear associated with a secondary structure $[61,68-70]$. The topographic growth in the sedimentary basins, on the eastern edge of the Sierras Pampeanas, shows the progressive deformation towards the east, obstructing and diverting surface drainage. The Alto de Mansilla is a topographic elevation just $130 \mathrm{~m}$ high, generated by convergent heading faults and overlapped with step-over restraining bend geometry, which divided a large lake and turned it into the Salinas Grandes and Salinas de Ambargasta [17].

In the alluvial fans of the foothills of the La Candelaria range (Santa Bárbara System) topographic highlights attributed to neotectonic activity and related to seismic events were observed [71]. On both flanks of this mountain range the geometry of the faults was determined, some blind, riding quaternary alluvial fans, making profiles with 2D electrical resistivity tomography, with seismic methods and with digital terrain models prepared with images obtained with drones. Repeated offsets during moderate-to-large earthquakes in the Quaternary are the most likely origin for these scarps, which suggests recurrent, spatially disparate seismogenic quaternary deformation processes in the broken foreland [72-75].

The sedimentary cover in the Cretaceous Rift basins is very thick (3554 m in the Metán basin, $3000 \mathrm{~m}$ in the Choromoro basin and $7000 \mathrm{~m}$ in the Tucumán basin) $[45,46,76]$, so the Neogene and Quaternary deformation folded these sedimentary piles, laying them on the Proterozoic-Paleozoic basement that is exposed in small outcrops, in the upper parts of the mountains. This tectonic morphology is mainly due to the inverse reactivation of normal faults inherited from the Cretaceous Rift, sometimes blind [43-46]. In the Metán basin, recent deformation was documented in folded surfaces, associated with blind and inherited structures. A case study with deep seismic and shallow geophysical prospecting methods evidenced the deformation produced by the El Galpón fault, folding neogenic and quaternary units, which would have experienced a seismic movement of M 5.7 in 2015 (Aranda-Viana Pers. Com.).

In the Cafayate valley, the Quaternary deformation produced folds in the lake deposits from the Upper Pleistocene to the Middle Holocene, evidencing the reactivation of the main high-angle faults, verging to the west, of the eastern edge of the valley, generating secondary faults that affect the quaternary coverage [77]. 


\section{Results}

In the Tafí and Amaicha valleys (Fig. 2), in the foothills of the south end of the Cumbres Calchaquíes, the surface relief is disturbed by structures wich was generated during neotectonic activity that give the landscape a morphology that breaks the monotony of the forms generated by alluvial fans and the fluvio-aeolian erosion. These structures sometimes occur, in the piedmont, far from the pre-existing larger structures, such as the examples cited in the literature $[61,67,78]$ and, other times, directly on the mountain front. The Sierra de Aconquija and Cumbres Calchaquíes mountains are limited by two faults; the Tafí del Valle fault marks the southern edge of the Cumbres Calchaquíes and the Los Cardones (Amaicha valley) and Carapunco (Tafí valley) faults the north edge of the Sierra de Aconquija (Fig. 2).

\subsection{Amaicha valley}

The Amaicha valley is narrow, with an average width of about $4 \mathrm{~km}$ (Fig. 1). The developed piedmonts belong to the southern foothills of the Cumbres Calchaquíes, it is covered by Sequences III and IV of the Santa María Group and the Quaternary alluvial fan deposits (Fig. 2; Table 1).

We consider that the Tafí del Valle fault had a normal component that separated the Sierra de Aconquija from the Cumbres Calchaquíes and formed the valleys of Tafí and Amaicha. This fault allowed the deposition of the Tertiary sequence in the Amaicha valley, therefore which results from an underdeveloped heritage from the Cretaceous Rift [7] (Figs. 1, 2, 5). Probably, the Tafí del Valle fault could have had an incipient development during the
Cretaceous Rift stage, which did not prosper. Sediments of Cretaceous or Tertiary age were not yet found in the Tafí valley, possibly because the area remained elevated, until in the lower Tertiary it began to partially fill up on the Amaicha valley side, reaching the Neogene deposits at the foot of the Infiernillo fault. As an example, remnants of the lower Tertiary red sediments (Santa Bárbara Subgroupe) occur at the foot of the Los Corpitos and Chasquivil faults (Figs. 1, 2, 3b).

Neogene sedimentary sequences of the Santa Maria Group spread eastward into the Sierra de Aconquija, against the dipping ramp to the west, which was later cut by the reverse Infiernillo fault, vergent to the NW [7]. The Infiernillo fault separeted the Amaicha Valley from Tafí Valley and would have also facilitated the magmatic ascent that originated the vulcanites in the northern zone of the Sierra de Aconquija (Figs. 1, 2). The horizontal displacement of the Tafí del Valle fault is affecting the sedimentary sequence of the Santa María Group, in the Santa María valley [7].

In the Amaicha river we measured the plane of the Los Cardones fault. It is a reverse fault that dips to the NE. Due to the fact that the fault plane in the granite outcrops is broken, it was possible to measure a plane dipping $40^{\circ}$ to the NE (Figs. 5, 6). The Los Cardones fault cuts the Tafí del Valle fault and places the layers of the Los Corrales Formation with a $40^{\circ}$ dip to the east (Table 1 ; Figs. 2, 5, 6). Southwest of the Los Cardones fault, the layers of the Los Corrales Formation slope $20^{\circ}$ to the SE (Fig. 2).

In the Amaicha valley, tectonic activity is affecting the Quaternary conglomerate sequence. It is possible to see how the layers of the Andalhuala Formation are riding on the Yasyamayo Formation and the faults also affect the quaternary gravels (Table 1; Figs. 2, 7). These faults occur

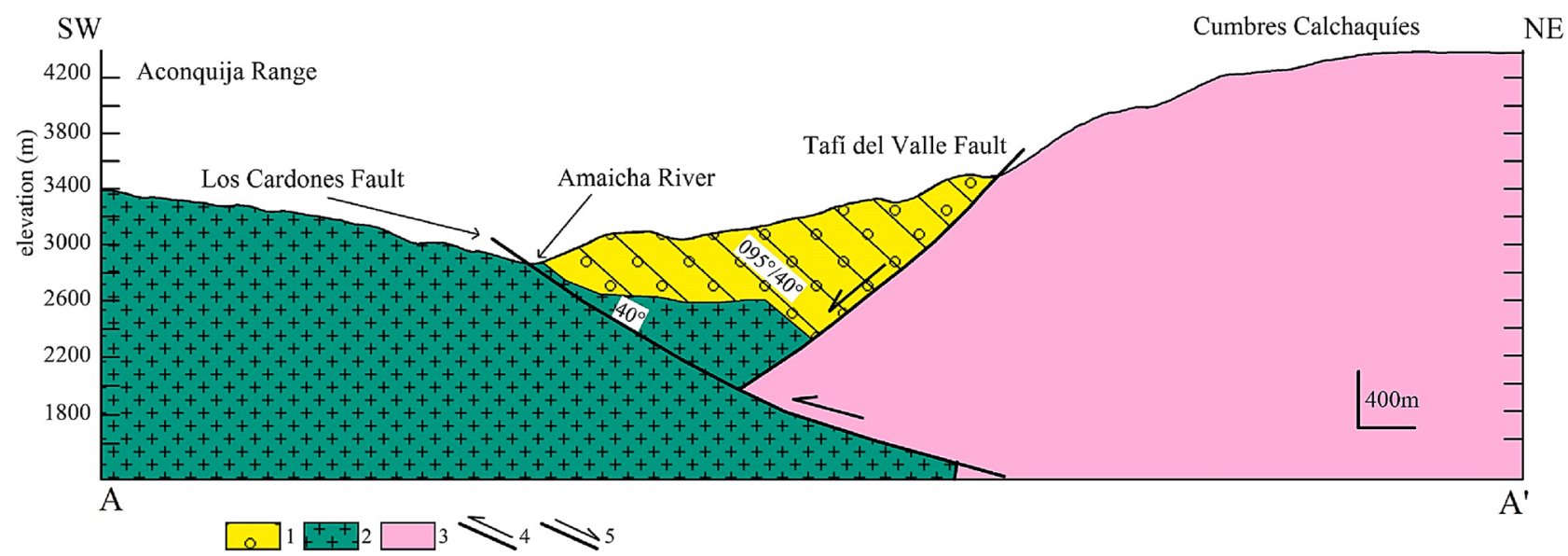

Fig. 5 Geological profile $A A^{\prime}$, transverse to the Amaicha valley. 1: Los Corrales Formation, Santa María Group, Neogene. 2: Paleozoic granite. 3: Proterozoic early - Paleozoic Basement. 4: Reverse fault. 5: Normal fault. The Los Cardones fault zone has a general dip direction to the $\mathrm{NE}$, dipping $40^{\circ}$ (Fig. 2) 
Fig. 6 a Photo illustrating the Los Cardones fault at the Amaicha Valley, documenting the profile in Fig. 5. The Los Corrales Formation, Santa María Group, Neogene rest on Paleozoic granites is observed. The complex is affected by the Los Cardones reverse fault that arrange the sedimentary layers of Los Corrales Formation dipping to the east. Stratification and fault plane measurements indicate $\mathrm{DD} / \mathrm{D}$. The white line is the contact between the granite and the Los Corrales Formation. Bedding in the Los Corrales Formation is marked with yellow lines. b Diagram of resulting fractures represented in Schmidt's equiareal network lower hemisphere. Los Cardones fault in the red line. In blue lines the faults in Fig. 7

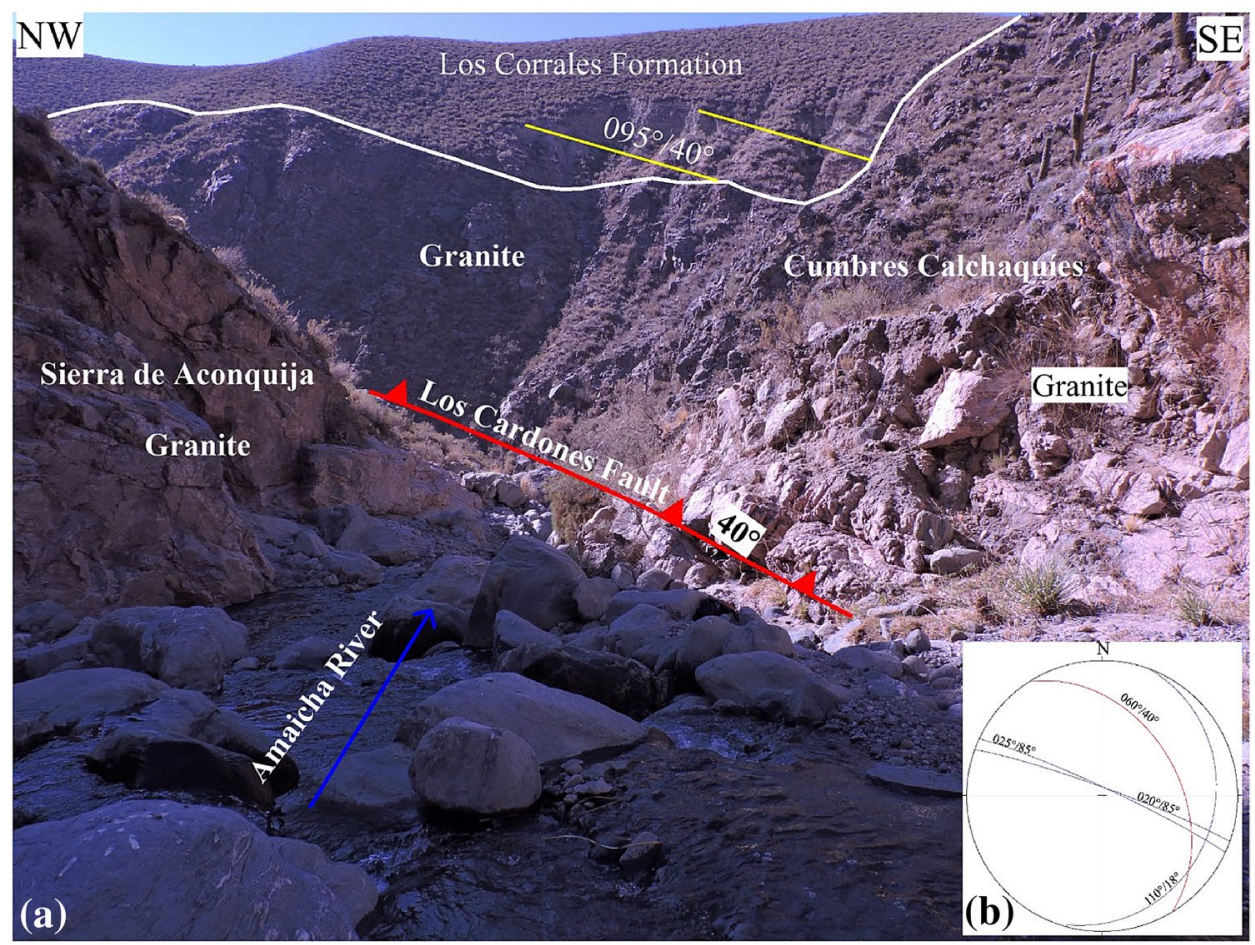

NNE

SSW

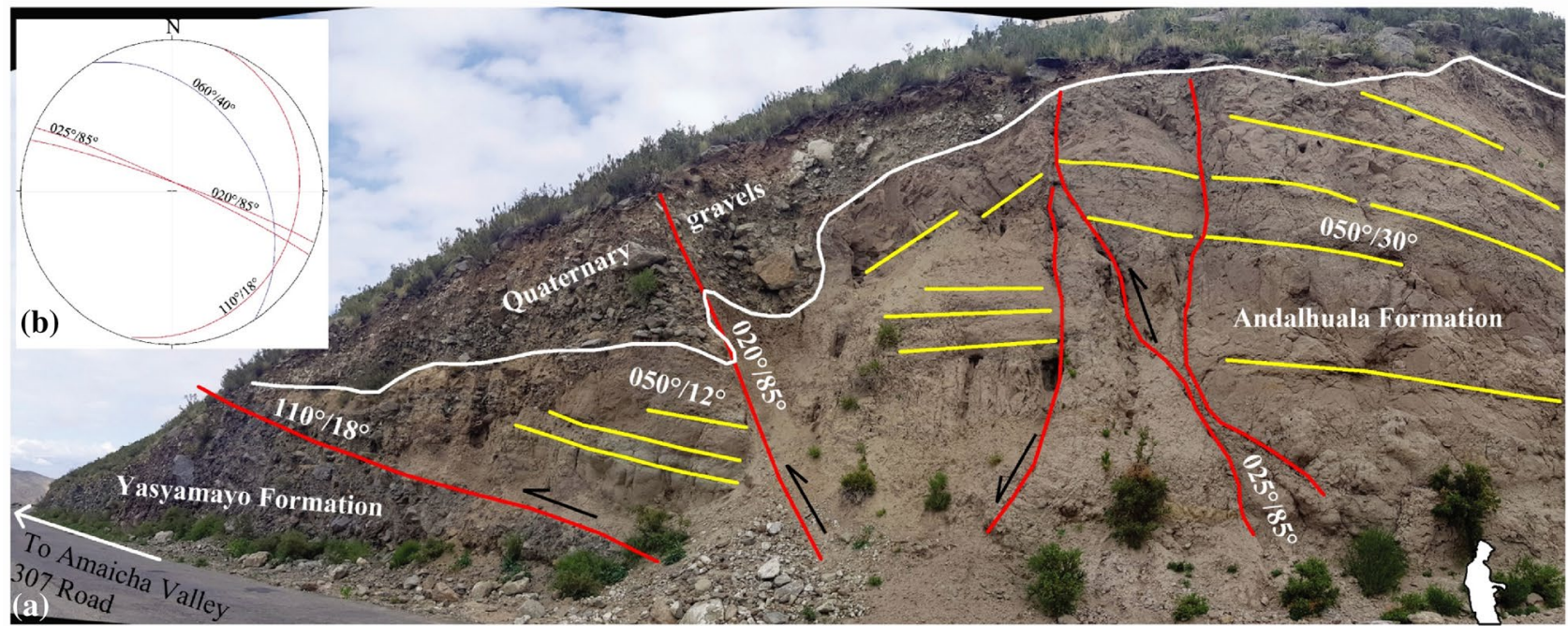

Fig. 7 a Photographic illustration in the Amaicha Valley. A reverse fault places the Andalhuala Formation on the Yasyamayo Formation. Other faults also affect quaternary gravels. The white lines mark the contacts of the sedimentary units. Yellow lines indicate bedding. Red lines are identifying structures. On the lower right

in the central zone of the valley, far from the main faults that limit the mountains. edge, in white, a person's half-length silhouette indicates scale. b Diagram of resulting fractures represented in Schmidt's equiareal network, lower hemisphere. Los Cardones fault in blue line. In red lines faults in this figure

\subsection{Tafí valley}

In the Tafí valley, alluvial fans are fed from both Cumbres Calchaquíes and Sierra de Aconquija. The deposits corresponding to the Cumbres Calchaquíes are

\section{SN Applied Sciences}


better developed, cover the entire mountain front of the southern edge and reach up to $4 \mathrm{~km}$ wide. On the other hand, the deposits in the foothills of the Sierra de Aconquija occupy only half of the northern front of the mountain range and are 2 or $3 \mathrm{~km}$ wide (Fig. 2). The thickness of the Quaternary deposits at the Mesada Lamedero is estimated to be about $200 \mathrm{~m}$.

Peña-Monne and Sampietro-Vatuone [30] defined in Tafí valley morphosedimentary units constituting aggradation phases. Unit $\mathrm{H} 1$ represents the oldest hillside accumulations, river terraces and alluvial cones, consisting of well-stratified coarse sands and gravels. Unit $\mathrm{H} 2$ occupies a large area constituting alluvial fan deposits made up of sediments similar to $\mathrm{H} 1$ (Table 1 ).

The differential tectonic behavior of both mountain blocks (Sierra de Aconquija and Cumbres Calchaquíes) generated the segmentation of the NW structures that limit both mountain ranges, the Tafí del Valle fault on the southern edge of the Cumbres Calchaquíes and Los Cardones-Carapunco faults on the edge north of the Sierra de Aconquija (Figs. 1, 2). This differential behavior can be observed in the Los Cardones and Carapunco faults (Fig. 2). Apparently the Los cardones fault only has dip-slip. On the other hand, the Carapunco fault has vertical and horizontal displacement. The Tafí valley reflects a differential tectonic behavior in neotectonic processes; several zones are distinguished in the foothills of the Cumbres Calchaquíes (Las Tacanas, La Costa II, Los Cuartos, Las Siringuillas and La Angostura), limited to the west by the Portuguese fault and to the east by the Chasquivil fault (Fig. 2).

\subsubsection{Las tacanas}

The Carapunco fault marks the northern limit of the Sierra de Aconquija, through it the river Tafí del Valle runs. The fault begins in the El Infiernillo pass and ends in the La Angostura area (Fig. 2). Towards the Tafí del Valle river, the alluvial fans of the Cumbres Calchaquíes and the Sierra de Aconquija converge.

In the Las Tacanas area, it is observed in the satellite images and in the geomorphology of the landscape, that the alluvial fans of the Cumbres Calchaquíes were reworked and modeled by other processes, different from the accumulation and erosion that characterize these geoforms. These surfaces are furrowed by deep, parallel and curved ravines that descend from the Cumbres Calchaquíes and end in the Tafí del Valle river, forming positive reliefs and hills between them (Figs. 2, 8). This drainage network with a curved and parallel pattern is represented by deep ravines generated by reverse faults that formed a series of ascending steps to the NW in the foothills (Fig. 8a). In this área, retrograde erosion and landslides on the southern slopes of the streams due reverse faults that changes the local base level, allow evidence of recent tectonic activity. These neotectonic indicators are consistent with the deformation associated with the recent seismic activity recorded in the área (Table 2 ).

In the upper parts of the foothills, the strata of a sequence of sandy silts, of a light brown color, with intercalations of conglomerate lenses, with large clasts, maintain an inclination of $18^{\circ}$ to the south (Fig. 9a). Together, these streams and the Tafí del Valle River form an interlaced contractional fan geometry (Fig. 8b), like the examples from the literature $[79,80]$. This geometry allows us

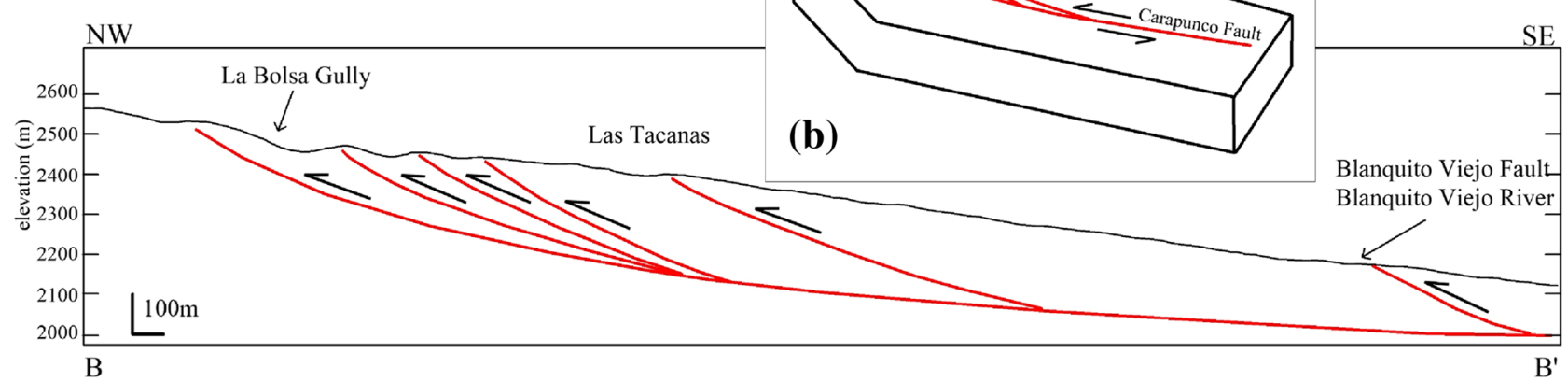

(a)

Fig. 8 a Topographic profile BB' showing the positive relief and the hills formed in the foothills of the Cumbres Calchaquíes, generated by reverse faults, configuring a rough surface limited by deep ravines. $\mathbf{b}$ The plant diagram shows an interpretation of the geom- etry of interposed contractional fans drawn based on the distribution of the drainage network in Fig. 2 and the attitudes of the fault planes 

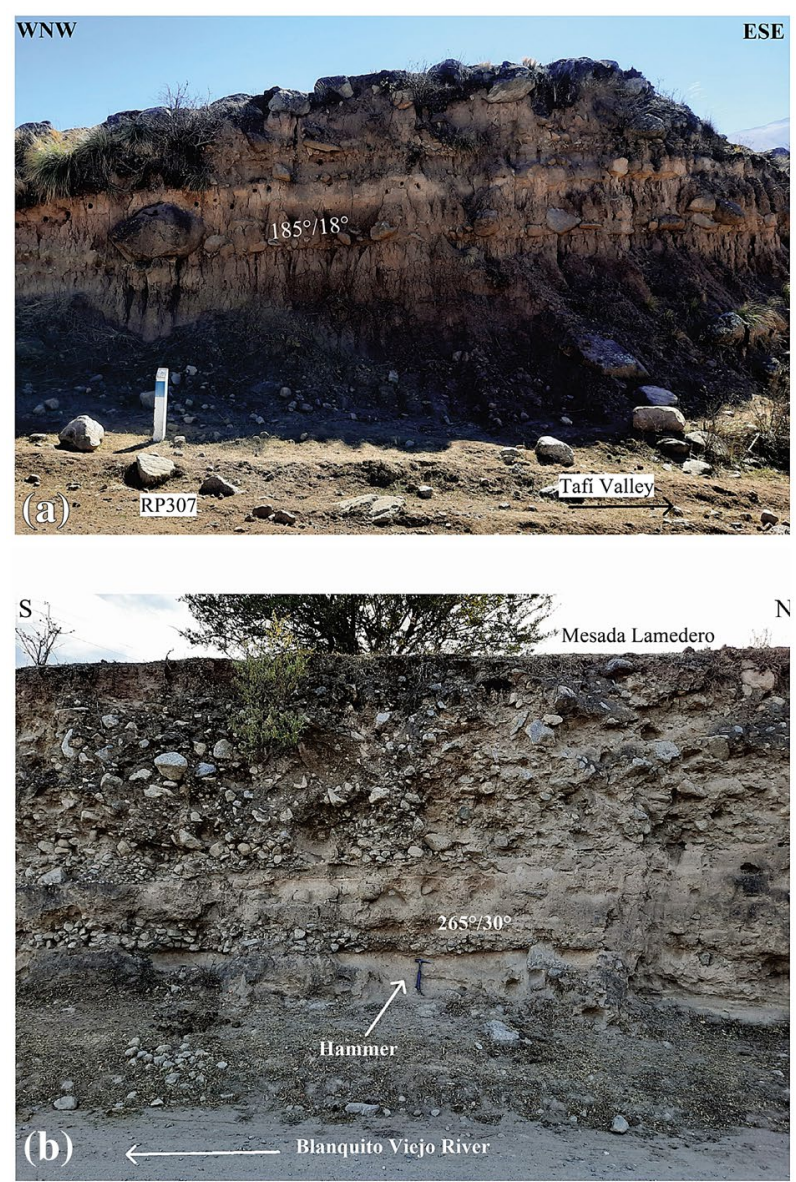

Fig. 9 a Stratigraphic sequence of the foothills on the right bank of the La Bolsa ravine. The conglomerate strata slope south $\left(185^{\circ} / 18^{\circ}\right)$. b Quaternary terrace on the right bank of the Blanquito Viejo river. The sequence was affected by the Blanquito Viejo fault, disposing the conglomerate strata with a west $\operatorname{dip}\left(265^{\circ} / 30^{\circ}\right)$

to determine that the Carapunco fault has a synestral transcurrent component (Figs. 2, 8b).

The Cumbres Calchaquíes are exerting pressure on the Sierra de Aconquija, generating the deformation of the foothills of the valley, in such a way that the foothills of the Cumbres Calchaquíes are higher than the foothills of the Sierra de Aconquija (Fig. 10a). This tectonic process that generates a characteristic morphology and a typical structural geometry is evidenced in the Mesada Lamedero (Fig. 10). There, a positive relief structure is formed by the Carapunco and Blanquito Viejo reverse faults, arranging the conglomerate layers of the alluvial fans of the Cumbres Calchaquíes with a strong east and west dips (Figs. 2, 9b, 10).

Figure 10 shows the ravine raised on the left bank of the Tafí del Valle river. On the right bank of the Blanquito Viejo river, the river terrace is made up of light brown sandy silts, with intercalations of conglomerate lenses at the base, passing into a fanglomerate in the upper half of the profile. The conglomeradic lenses dip $30^{\circ}$ to the west $\left(265^{\circ} / 30^{\circ}\right)$, product of the activity of the Blanquito Viejo fault (Figs. 9b, 10).

\subsubsection{La Costa II, Los Cuartos}

These zones are located in the southeast end of the Tafi valley, where the Tafí del Valle and Chasquivil faults converge (Figs. 2, 11). In this area, the Loma Pelada constitutes a positive element that divides the Tafí valley (Fig. 2). The foothill deposits of the Sierra de Aconquija are better developed in the Las Carreras valley, but not on the eastern edge of the Loma Pelada, which is where the piedmonts deposits of the Cumbres Calchaquíes will end up, against the Tafí del Valle River (Figs. 2, 11).

Quaternary structures were generated both in the foothills and in the mountain front of the Cumbres Calchaquies (Fig. 11). In these areas we were able to make measurements of structures and verify the folds of the conglomerate banks of the outcrops. In other nearby areas such as Las Siringuillas, Las Nubes and La Angostura we do not find outcrops where structures can be measured, but the deformation of the alluvial fans adequately reflects neotectonic activity (Figs. 11, 12).

In the La Costa II área, the tectonic deformation of the Quaternary sediments occurs on the mountain front. Here we can see the cuspid zone of the deformed dejection cones, ridden by metamorphic basement, through a reverse fault dipping to the ENE $\left(080^{\circ} / 80^{\circ}\right)$ (Fig. 11). This fault corresponds to a reactivation of the Tafí del Valle and Chasquivil faults and the quaternary sediments would be represented by the $\mathrm{H} 1$ accumulations [30] (Figs. 2, 11). Other reverse faults $\left(130^{\circ} / 88^{\circ}, 280^{\circ} / 50^{\circ}, 115^{\circ} / 80^{\circ}\right)$, measured in metamorphic basement, also affect the quaternary sedimentary sequence. One of these faults $\left(045^{\circ} / 90^{\circ}\right)$ coincides with the Tafí del Valle fault (Fig. 11). Here, the quaternary faults are affecting the accumulations identified as H1, dated by Peña Monné and Sampietro Vattuone [30] between ca. 13000 and 4200 a BP (Fig. 11; Table 1).

In this area, rock falls by destruction of the terraces on the margins of the ravines are also observed, which allow evidence of recent tectonic activity. The discrete deformation (Table 2) associated with the recent seismic activity recorded in the area generates these neotectonic indicators.

Between the Los Cuartos and Las Siringuillas area, the piedmont landscape is crossed by structures with NW and NE strike and disturbed by hills of about 400 to $800 \mathrm{~m}$ in length and $140 \mathrm{~m}$ in width, with NNW strike (Figs. 11, 12). These hills are made up of Pleistocene sediments and are deforming the $\mathrm{H} 1$ and $\mathrm{H} 2$ accumulations (Figs. 11, 12; Table 1). Two anticline fold structures are observed, with NW and NE strike, which dispose the 

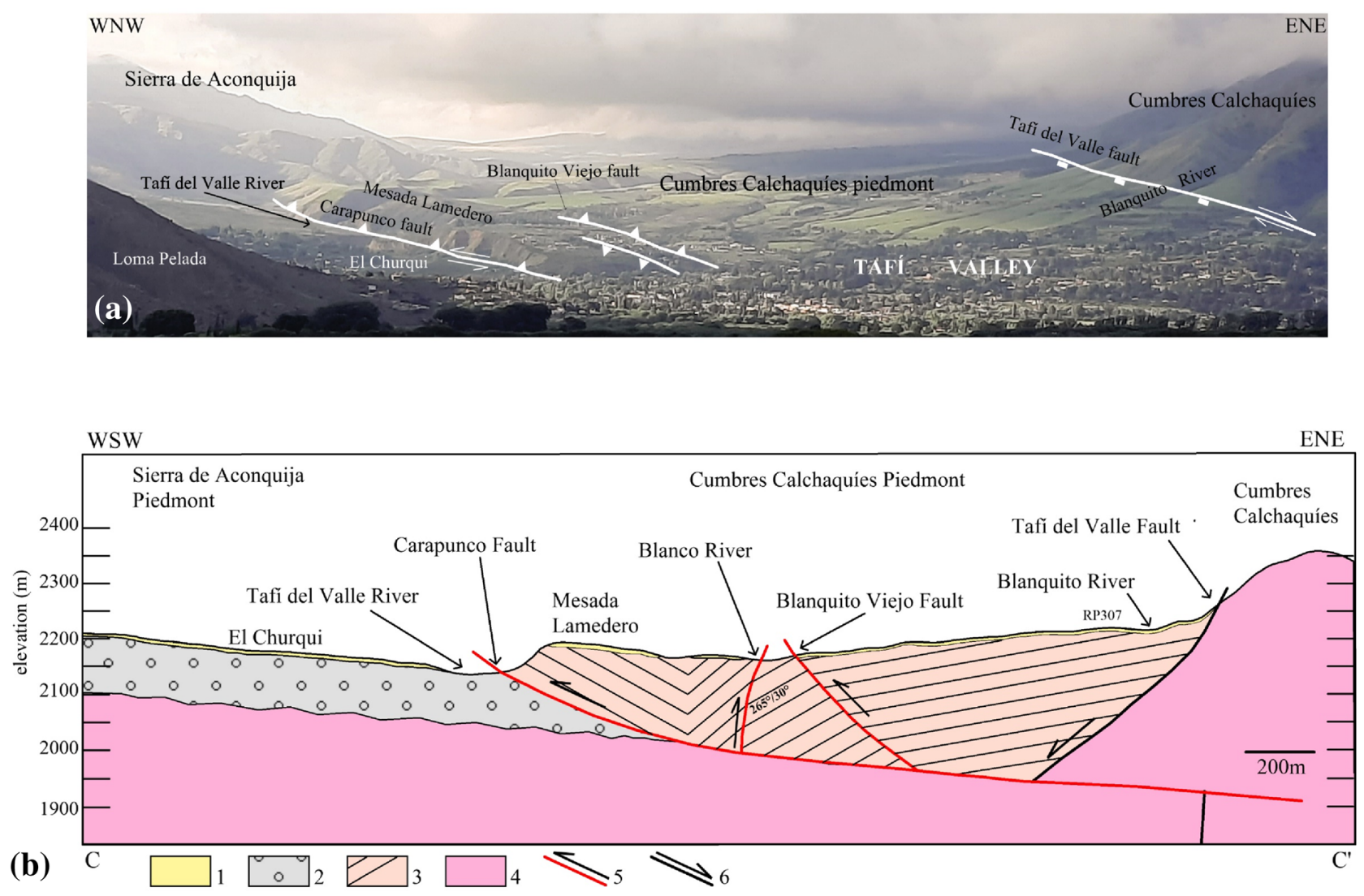

Fig. 10 a Panoramic view of the Tafí Valley tectonics morphology displayed in figure $\mathbf{b}$. We can see the topographic relief of the alluvial fans disturbed by the reverse faults generating the counter slope. It is also observed how the piedmonts of the Cumbres Calchaquíes rise above the Sierra de Aconquija piedmonts, through the Carapunco fault. b CC' topographic profile showing the Mesada
Lamedero positive relief structure, formed by the Carapunco and Blanquito Viejo faults. It is observed that the foothills of the Cumbres Calchaquíes are raised and folded over the foothills of the Sierra de Aconquija. 1: Loess deposits (Q). 2: Alluvial fan deposits (Q). 3: Alluvial fan deposits (Q). 4: Proterozoic basement. 5: Recent reverse faults. 6: Normal fault
Pleistocene conglomerate strata dipping to the NE, SW and SE, NW, respectively (Fig. 13; Table 1).

The faults have reverse displacement, dipping to the NW and NE $\left(300^{\circ} / 45^{\circ}, 080^{\circ} / 80^{\circ}, 125^{\circ} / 70^{\circ}, 115^{\circ} / 85^{\circ}\right.$, $\left.060^{\circ} / 84^{\circ}\right)$. One of them $\left(060^{\circ} / 84^{\circ}\right)$ also evidenced dextral transcurrent movement, dividing one of the hills and generating a typical whale-back structure and a fault gap (Figs. 11, 14). Other structures are affecting the folds and $\mathrm{H} 1$ and $\mathrm{H} 2$ accumulations (Figs. 11, 12; Table 1).

The faults generated in the area between Los Cuartos are found in the cuspid part of the alluvial fans, near the mountain front and generate anticline folds in the Pleistocene deposits (Fig. 11, 13; Table 1). These structures and associated morphologies appear to be closely related to the Chasquivil fault. The layers of the $\mathrm{H} 2$ accumulations, dated by Peña Monné and Sampietro Vattuone [30] between ca. 4200-630 to BP are also affected by tectonic activity (Fig. 13a). The drainage network also shows tectonic activity, the channels are interrupted and diverted by the anticline structures and show recent incision in the $\mathrm{H} 2$ accumulations (Figs. 11, 12).

\section{Discussion}

The NE compression due to the convergence of the Nazca and South American plates produces deformation through movement in faults of diverse geometries. The deformation is influenced, among other things, by the rheology of the rocks and pre-existing faults $[22,40,45-47,67,81-83]$.

Seismic rupture occurs when the elastic stress to which the rock is subjected exceeds its frictional resistance $[53-60,66,67]$. Most of the earthquakes recorded in the study area are of magnitude 3 and 4 , which produce mean displacements of 1 and $3 \mathrm{~cm}$ (Table 2), respectively. The intense deformation of the foothills of the Tafí and Amaicha valleys shows a sustained tectonic activity over time, marked in the sediments of $630 \mathrm{BC}$ and by 


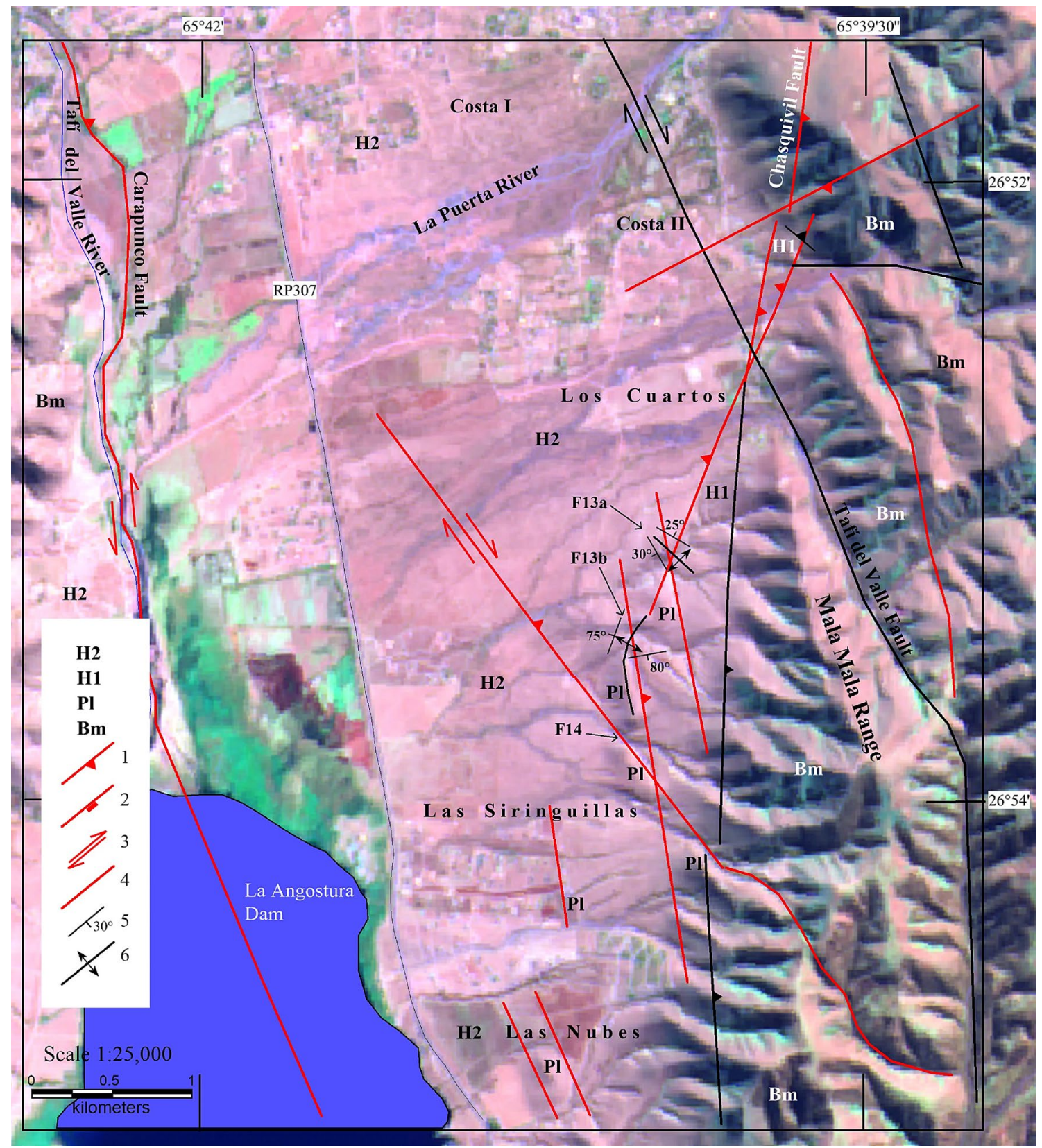

Fig. 11 Image map (Sentinel image) of the southeast end of the Tafí valley to show recent structures in the foothills. $\mathrm{H} 1$ and $\mathrm{H} 2$ : Accumulations, morphosedimentary units of the Holocene [30]. PI: Pleistocene. Bm: Upper Proterozoic metamorphic basement. -

recent seismic activity, which, despite being of low intensity, the small recurrent deformation and cumulative that it produces is capable of generating discrete deformations in the landscape, sometimes imperceptible to the human eye.

Recent earthquakes would be linked to one of the faults in the region (Tafí del Valle, Chasquivil, Aconquija, Periquillo, Río Muerto and Narváez faults and with the Los Pinos lineament) (Fig. 1).
Lower Paleozoic. Recent structures are shown in red and old structures in black. 1: Reverse fault. 2: Normal fault. 3: Transcurrent fault. 4: Lineaments. 5: Bedding strike and dip. 6: Anticline fold. F13 and F14 indicate the location of these figures

Both in the Amaicha valley and in the Tafí valley, the tectonic deformation occurred in the foothills. The structures generated in the foothills are represented by reverse, normal and transcurrent faults and anticline folds (Figs. 3a, $6,7,8,10,13,14)$. We interpret that the deformation occurs in the foothills because the sediments that fill these valleys have less cohesion and frictional resistance than the planes of the pre-existing faults that favor the dissipation of the seismic energy generated by tectonic activity.

\section{SN Applied Sciences}




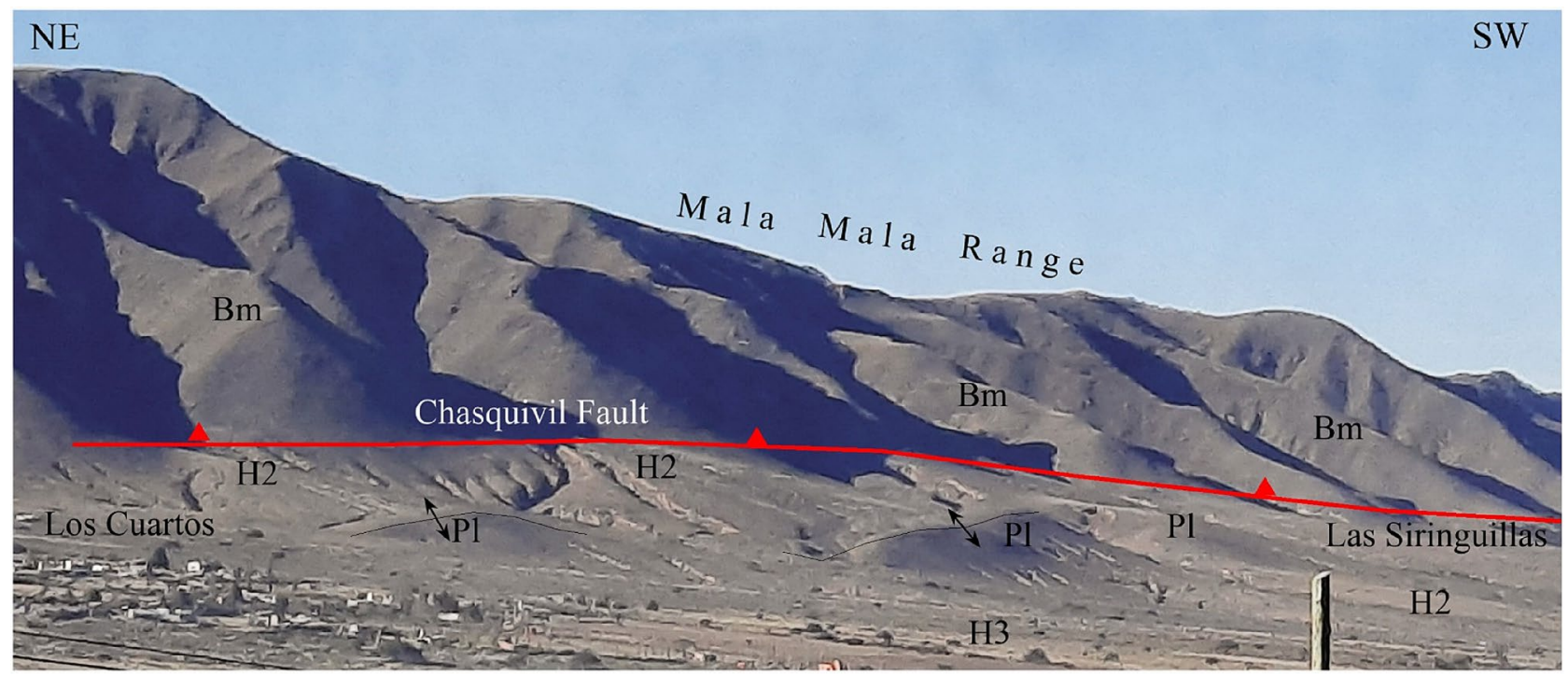

Fig. 12 Photo showing the deformation of the piedmont by neotectonic processes associated with the Chasquivil fault. Hills oriented to the NNW are observed, made up of Pleistocene sediments, modifying the course of surface drainage, disturbing the $\mathrm{H} 2$ accumulations. Symbols are explained in Fig. 11

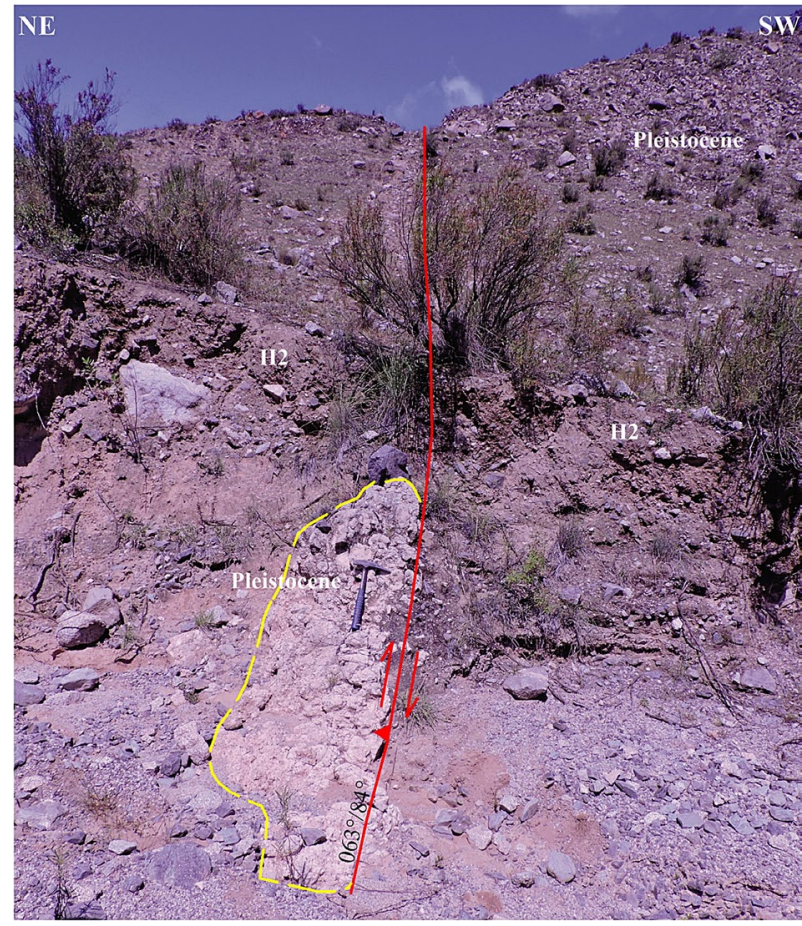

Fig. 14 View of a dextral transcurrent fault, with a vertical displacement component, affecting an outcrop of Lomitas Pegadas Formation of Pleistocene age. On the surface of the ground you can see the falt scar. At the bottom there is a terrace on the left bank of the stream, made up of $\mathrm{H} 2$ accumulations. The fault gap is visible in the stream bed. The hammer serves as a scale

Consequently, the seismic energy is attenuated by the deformation of the pedemontane deposits (Figs. 7, 10, 12, 13 ) instead of being abruptly released by the breakdown of the basement rocks (Fig. 4). 
As an example that materials with less cohesion and frictional resistance favor the dissipation of seismic energy and, consequently, tectonic deformation occurs in the first instance on these materials, we cite the Neogene tectonic deformation that occurred in the Cretaceous basins of northern Argentina and in the piedmont deposits of other regions. In the Cretaceous Rift basins, normal faults were reactivated as reverse faults [43-46] due to frictional resistance in the pre-existing faults planes is less than that of the rock of the sedimentary packages and also because the strike of these pre-existing faults is perpendicular to the Andean compression. The seismic profiles of the rift basins (Metán and Tucumán basins) show the reverse reactivation of cretaceous normal faults, with no new faults forming $[45,46]$. A similar situation occurs in the western foothills of the La Candelaria range where a reverse, blind fault, vergent to the east, was generated taking advantage of the stratification planes of the tertiary sequence $[73,75]$ that offered less cohesion and frictional resistance.

But, in the study area and to the west of the Tucumán basin, the Cretaceous Rift faults did not have great development and large and deep basins were not formed (Las Cañas, Río Muerto, Periquillo, Chasquivil, Aconquija, Cumbres Calchaquíes and Portugues faults and the Los Pinos lineament). Only red sediments from the Lower Tertiary outcrops (Santa Bárbara Subgroup), there are no sediments corresponding to other secuences of the Cretaceous rift (Fig. 3) and the landscape is dominated by rocks from the Proterozoic basement. In addition, some normal faults inherited from the Cretaceous Rift (Los Corpitos, Infiernillo, Tafí del Valle, Las Cañas) were not reactivated, they were cut by the reverse neogenic and quaternary faults $[6,7,22,47]$.

Several seismic foci of magnitude $\geq 3$ are located on the trace of the Chasquivil and Tafí del Valle faults (Fig. 1). This recent tectonic activity generates retrograde erosion, mobilizes and loosens the structural framework of the conglomerate deposits of the fluvial terraces and of the alluvial fans and of the regoliths of the metamorphic basement, triggering tumble falls and consequent landslides (Figs. 4, 11, 12, 13).

In the Tafí valley, the deformation of the Lomitas Pegadas Formation shows tectonic movements in the Upper Pleistocene [33]. In the Tafí valley the deformation of the foothills is greater than in the Amaicha valley, perhaps due to the fact that the valley fill consists only of deposits of quaternary alluvial fans, of less cohesion.

In the foothills of the Cumbres Calchaquíes, in the Tafí del Valle area, two structural zones are distinguished that show the differential propagation of seismic energy and consequently deformation. In the southeast sector of the valley, the deformation was directed by the Chasquivil fault and was confined by the Loma Pelada range to the west, and by the convergence of the Cumbres Calchaquíes and Sierra de Aconquija, to the southeast (Fig. 2). Consequently, in the foothills zone there were reverse and transcurrent faults and very tight folds; no evidence of displacement of the Carapunco fault was found in this area (Figs. 2, 12, 13, 14). The monotony of the foothills landscape is interrupted by folds and fractures. These tigger the diversion of the drainage channels whose recent incision is marked in the $\mathrm{H} 2$ deposits (Figs. 11, 12). Towards the northwest, the Tafí valley ends against the El Infiernillo pass, where once again the Sierra de Aconquija and the Cumbres Calchaquíes are held together by a partially buried igneous-metamorphic body (Fig. 2). In addition to the lower cohesion of the piedmont deposits, the seismic energy propagated and deformation taking advantage of the opening of the valley in the extreme northwest (Fig. 2). The sinistral component of the Carapunco fault generated an imbricated system of contractional faults with fan geometry (Figs. 2, 8) and the reverse component produced the thrust of the Cumbres Calchaquíes piedmont on the alluvial fan deposits of the Sierra de Aconquija (Fig. 10).

The hypotheses of Ruiz Huidobro [1], Ferreiro and Mon [2], González [3] and González and Barreñada [4] are verified, the Amaicha valley is delimited to the north by the Tafí del Valle normal fault and to the south by the Los Cardones fault (Figs. 2, 5, 6). In the Amaicha valley the neotectonic deformation of the piedmont is associated with the Los Cardones fault and other faults in the pedemontane area (Figs. 1, 2, 5, 6, 7).

\section{Conclusions}

The neotectonic deformation in the Tafí and Amaicha valleys occurred in the foothills of the Cumbres Calchaquíes through folds and fractures with NE and NW strike. Some fractures experienced horizontal movements in both directions and others had reverse displacements, retrovergent with respect to the Andean deformation (Fig. 2).

In the study region there are many earthquakes of magnitude $\geq 3$ and together with some of magnitude $\geq 4$ coincide with regional faults (Tafí del Valle, Chasquivil, Río Muerto, Los Pinos). This coincidence shows that these regional faults are active (Fig. 1 ).

The presence of two faults that limit the Amaicha valley is confirmed. To the north it limits with the Cumbres Calchaquíes through a normal fault that slopes towards the SW and has a horizontal dextral component (Fig. 2). To the south it is bounded by the Sierra de Aconquija through the reverse Los Cardones fault, vergent to the SW (Fig. 2). In the piedmont of this valley the Andalhuala Formation strata ride over the conglomerates of the Yasyamayo Formation 
and the quaternary gravels are also affected by these faults (Figs. 2, 7).

The Cumbres Calchaquíes ride over the Sierra de Aconquija through the Los Cardones and Carapunco faults (Figs. 2, 10). In the Mesada Lamedero the Carapunco fault has $176 \mathrm{~m}$ of fault offset (Fig. 10). The Carapunco fault also has a horizontal synestral component that is responsible for generating an imbricated system of contractional fractures, curved in plan, in the piedmont deposits of the Cumbres Calchaquíes in the Las Tacanas area (Figs. 2, 8). In the southeast end of the Tafí valley (La Costa II, Los Cuartos, Las Siringuillas, Las Nubes, La Angostura) the neotectonic activity has generated faults and folds in the foothills affecting the conglomerate sequences of the Pleistocene Lomitas Pegadas Formation (Figs. 11, 12, 13, 14). Tectonic activity in the piedmont of Cumbres Calchaquíes are affecting deposits dated 630 a BP.

The alluvial fan deposits in the piedmonts, as they have less cohesion and frictional resistance than the fillings of the pre-existing faults, absorb and attenuate the seismic energy propagated. On the other hand, the strike of the pre-existing faults and the arrangement of the stratification planes of the sedimentary sequence with respect to the Andean compression can be favorable to the reactivation of these planes.

In the study area, the normal faults of the Cretaceous Rift, with unfavorable orientations with respect to the Andean compression, were not reactivated (Las Cañas fault, Tafí del Valle fault). Even other $\mathrm{N}$ and NE strike faults (Infiernillo, Los Corpitos, Portugués) were cut by faults with opposite strike and senses. However, the reverse reactivation of the Chasquivil fault, with west vergence, produced the tilting towards the SE of quaternary conglomerate deposits $\left(110^{\circ} / 12^{\circ}\right)$ on the left bank of the Los Sosa River, in the La Angostura area, and of red sediments from the Paleogene, in the riverbed of the same river (Figs. 1, 2, 3, 11, 12).

Acknowledgements This work was carried out with the support of the National University of Tucumán and the financing of the Argentine-German University Center. The authors express their gratitude to Dr. Francésc Sabat Monserrat for the critical reading of the manuscript and his valuable suggestions. Also a special recognition to the reviewers, Dr. Lucio Pinotti and other, who with their criticisms and suggestions contributed to substantially improve the paper.

\section{Declarations}

Conflict of interest On behalf of all authors, the corresponding author states that there is no conflict of interest.

Open Access This article is licensed under a Creative Commons Attribution 4.0 International License, which permits use, sharing, adaptation, distribution and reproduction in any medium or format, as long as you give appropriate credit to the original author(s) and the source, provide a link to the Creative Commons licence, and indicate if changes were made. The images or other third party material in this article are included in the article's Creative Commons licence, unless indicated otherwise in a credit line to the material. If material is not included in the article's Creative Commons licence and your intended use is not permitted by statutory regulation or exceeds the permitted use, you will need to obtain permission directly from the copyright holder. To view a copy of this licence, visit http://creativecommons. org/licenses/by/4.0/.

\section{References}

1. Ruiz-Huidobro OJ (1972) Descripción geológica de la Hoja 11 e, Santa María, provincias de Catamarca y Tucumán. Servicio Nacional Minero Geológico, Boletín, 134, 65 pp

2. Ferreiro VJ, Mon R (1973) Geomorfología y Tectónica del Valle de Santa María. Acta Geológica Lilloana 5:127-136

3. González OE (2000) Hoja Geológica 2766-II San Miguel de Tucumán 1:250,000. Secretaría de Energía y Minería, 124, 78 $\mathrm{pp}$

4. González OE, Barreñada O (1994) Geología y Estructura de las nacientes del río Amaicha y El Infiernillo, provincia de Tucumán. Actas XII Congreso Geológico Argentino y I de Exploración de Hidrocarburos 3:72-80

5. Gutiérrez AA, Mon R, Vergara G (2003) Neotectónica: captura y decapitación del drenaje, Tucumán-Argentina. Congreso Argentino de Cuaternario y Geomorfología, Actas II, 293-300, Tucumán

6. Gutiérrez AA, Mon R (2004) Megageomorfología del valle de Tafí-Aconquija, Tucumán. Revista de la Asociación Geológica Argentina 59(2):303-311

7. Mon R, Gutiérrez AA, Sábat F, laffa D (2012) A Miocene Continental Basin associated with the back thrusting of the Eastern Sierras Pampeanas in the Santa Maria Valley, Northwestern Argentina. Italian J Geosci (Boll.Soc.Geol.It.) 131(1):123-135. https://doi.org/10.3301/IJG.2011.27 (Roma)

8. Baldis B, Viramonte J, Salfity J (1975) Geotectónica de la comarca comprendida entre el Cratógeno Central Argentino y el borde austral de la Puna. Segundo Congreso Ibero-Americano de Geología Económica 4:25-44

9. González Bonorino F (1950) Geología de la Hoja 13e Villa Alberdi (provincias de Catamarca y Tucumán). Dirección Nacional de Industria y Minería, Buenos Aires. 66 pp

10. Schwanghart W, Scherler D (2014) TopoToolbox 2 e MATLABbased software for topographic analysis and modeling in Earth surface sciences. Short Commun Earth Surf Sci Earth Surf Dyn 2(1):1-7

11. Isacks B (1988) Uplift of the central Andean plateau and bending of the Bolivian orocline. J Geophys Res 93:3211-3231

12. Somoza R, Ghidella ME (2005) Convergencia en el margen occidental de América del Sur durante el Cenozoico. $16^{\circ}$ Congreso Geológico Argentino, Actas: 43-45. La Plata

13. Lavenu A (2006) Neotectónica de los Andes entre $1^{\circ} \mathrm{N}$ y $47^{\circ} \mathrm{S}$ (Ecuador, Bolivia y Chile): una revision. Revista de la Asociación Geológica, Argentina 61(4):504-524

14. Cristallini EO, Comınguez AH, Ramos VA, Mercerat ED (2004) Basement double-wedge thrusting in the northern Sierras Pampeanas of Argentina $\left(27^{\circ} \mathrm{S}\right)$ - Constraints from deep seismic reflection. In: K.R. McClay (ed) Thrust tectonics and hydrocarbon systems, vol 82. AAPG Memoir, pp 65-90

15. Bossi GE, Georgieff SM, Gavriloff IJC, Ibáñez LM, Muruaga CM (2001) Cenozoic evolution of the intramontane Santa María basin, Pampean Ranges, northwestern Argentina. J S Am Earth Sci 14:725-734

16. Mon R, Gutiérrez AA (2009) The Mar Chiquita Lake: An indicator of intraplate deformation in the central plain of Argentina. Geomorphology 111:111-122 
17. Gutiérrez AA, Mon R, Sàbat F, laffa DN (2017) Origin and evolution of the salinas grandes and Salina de Ambargasta, Argentina. In: World multidisciplinary earth sciences symposium, IOP conference series: earth and environmental science, vol 95. pp 022-036. https://doi.org/10.1088/1755-1315/95/2/022036

18. Mon R, Drozdzewski G (1999) Cinturones doblevergentes en los Andes del norte argentino - Hipótesis sobre su origen. Rev de la Asociación Geol Argentina 54:3-8

19. Turner JCM (1960) Estratigrafía de la sierra de Santa Victoria y adyacencias. Bol Acad Nac Cienc 41(2):163-196 (Córdoba)

20. Aceñolaza FG, Toselli AJ (1981) Geología del noroeste argentino. Publicación especial № 1287 de la Facultad de Ciencias Naturales e IML, Universidad Nacional de Tucumán, Argentina, 212 $\mathrm{pp}$

21. Porto JC, Danieli C, Ruiz-Huidobro OJ (1982) El Grupo Salta en la Provincia de Tucumán. V Congreso Latinoamericano Argentino. Actas IV:253-264

22. Gutiérrez AA, Mon R, Arnous A, Cisterna CE (2019) Sinestral rotation and NNW shortening of the ambato block induced by cenozoic NE to E-W transpression, Argentina. Int J Earth Sci Geol 1(2):74-85. https://doi.org/10.18689/ijeg-1000109

23. González OE (1990) Las vulcanitas del Portezuelo Las Ánimas, sierra de Aconquija, provincias de Catamarca y Tucumán. Revista de la Asociación Geológica Argentina XLV(3-4):386-396

24. Powell JE, González OE (1997) Hallazgo de mamíferos en la Formación Saladillo (Grupo Santa María), próximo al río Amaicha, provincia de Tucumán. Implicancias cronológicas Ameghiniana $34: 124$

25. Spagnuolo CM, Georgieff SM, Rapalini AE (2015) Magnetostratigraphy of the Miocene las Arcas formation, Santa María valley, northwestern Argentina. J S Am Earth Sci 63:101-113

26. Georgieff SM, Díaz A (2014) Modelo paleoambiental de la Formación Las Arcas (Mioceno Superior), quebrada del Mal Paso, Valles Calchaquíes del sur de Salta. Reunión Argentina de Sedimentología: 114. Puerto Madryn, Chubut, $2 \mathrm{pp}$

27. Butler RF, Marshall LG, Drake RE, Curtis GH (1984) Magnetic polarity stratigraphy and $40 \mathrm{~K}-40 \mathrm{Ar}$ dating of late Miocene and early Pliocene continental deposits, Catamarca Province, NW Argentina. J Geol 92(6):623-636

28. Marshall LG, Patterson B (1981) Geology and geochronology of the mammal-bearing Tertiary of the valle de Santa María and río Corral Quemado, Catamarca province, Argentina. Field Mus Nat Hist 9:1-78

29. Strecker MR, Bloom A, Carrión M, Villanueva A, Naeser C (1984) Piedmont terraces in the Valle de Santa María and in front of southwestern Sierra Aconquija. Actas del $9^{\circ}$ Congreso Geológico Argentino San Carlos de Bariloche 2:448-465

30. Peña-Monné JL, Sampietro-Vattuone MM (2018) Paleoambientes holocenos del valle de Tafí (Noroeste Argentino) a partir de registros morfosedimentarios y geoarqueológicos. In: Polanco JM, Frugone M (eds) Boletín Geológico y Minero. Paleoclimas en Iberoamérica. Un análisis mediante registros geológicos e indicadores ambientales, vol 129(4). pp 671-691

31. Sampietro-Vattuone MM, Peña-Monné JL, Roldán J, Dip AB, Maldonado MG, Lefebvre MG, Vattuone MA (2019) Land management and soil degradation evidence during the Late Holocene in Northwest Argentina (La Costa 2 - Tafí valley). Catena 182, Elsevier, $13 \mathrm{pp}$

32. López JP, Altenberger U, Bellos LI, Ferrocchio B, Llomparte Frentzel G (2017) Petrological and geochemical characteristics of EI Pabellón granite, Tafí del Valle, Tucumán, NW of Argentina. XX Congreso Geológico Argentino, Sesión Técnica 4, Petrología y Geoquímica de Rocas Ígneas, 62-68, San Miguel de Tucumán, Argentina
33. González OE (1999) Geología de La Angostura, valle de Tafí, Tucumán. XIV Congreso Geológico Argentino, Actas I:283-286

34. Collantes MM, Powell J, Sayago JM (1993) Formación Tafí del Valle (Cuaternario superior), provincia de Tucumán (Argentina): litología, paleontología y pleoambientes. XII Congreso Geológico Argentino y II Congreso de Exploración de Hidrocarburos, Actas II:200-206

35. Schellenberger A, Heller F, Veit H (2002) Magnetostratigraphy and magnetic suceptibility of the Las Carrerras loess-paleosol sequence in Valle de Tafí, Tucumán, NW de Argentina: paleoclimatic significance. XV Congreso Geológico, Calafate, Actas CDROM, Artículo N ${ }^{\circ} 317,4$

36. Garralla S, Muruaga C, Herbst R (2001) Lago El Rincón, Holoceno del departamento de Tafí del Valle, provincia de Tucumán (Argentina): palinología y facies sedimentarias. Publicación especial-Asociación paleontológica Argentina, Argentina, pp 91-99

37. Ortíz PE, Jayat JP (2007) Sigmodontinos (Rodentia: Cricetidae) del límite Pleistoceno-Holoceno en el valle de Tafí (Tucumán, Argentina): taxonomía, tafonomía y significación Paleoambiental. Ameghiniana (Revista de la Asociación Paleontológica Argentina) 44(4):641-660 (Buenos Aires)

38. Sampietro-Vattuone MM, Peña-Monné JL (2016) Geomorphological dynamic changes during the Holocene through ephemeral stream analyses from Northwest Argentina. CATENA 147:663-677. https://doi.org/10.1016/j.catena.2016.08.029

39. Marrett RA, Allmendinger RW, Alonso RN, Drake RE (1994) Late Cenozoic tectonic evolution of the Puna Plateau and adjacent foreland, Northwestern Argentine Andes. J S Am Earth Sci 7(2):179-207. https://doi.org/10.1016/0895-9811(94)90007-8

40. Riller U, Oncken O (2003) Growth of the Central Andes Plateau by tectonic segmentation is controlled by the gradient in crustal shortening. J Geol 111:367-384

41. Strecker MR, Cerveny P, Bloom AL, Malizia D (1989) Late Cenozoic tectonism and landscape development in the foreland of the Andes: Northern Sierras Pampeanas $\left(26^{\circ}-28^{\circ} \mathrm{S}\right)$. Argentina Tectonics 8:517-534

42. Mon R (1993) Influencia de la Orogénesis Oclóyica (OrdovícicoSilúrico) en la segmentación andina en el norte argentino. Decimosegundo Congreso Geológico Argentino 3:65-71

43. Grier ME, Salfity JA, Allmendinger RW (1991) Andean reactivation of the Cretaceous Salta rift, NW Argentine. J S Am Herat Sci 4:351-372

44. Carrera N, Muñoz JA, Sàbat F, Mon R, Roca E (2006) The role of inversion tectonics in the structure of the Cordillera oriental (NW Argentinean Andes). J Struct Geol 28:1921-1932

45. laffa DN, Sàbat F, Muñoz JA, Mon R, Gutiérrez AA (2011) The role of inherited structures in a foreland basin evolution. The Metán Basin in NW Argentina. J Struct Geol 33:1816-1828

46. laffa DN, Sàbat F, Bello D, Ferrer O, Mon R, Gutiérrez AA (2011) Tectonic inversion in a segmented foreland basin from extensional to piggyback settings: the Tucumán basin in NW Argentina. J S Am Earth Sci 31:457-474

47. Gutiérrez AA, Mon R (2008) Macroindicadores cinemáticos en el Bloque Ambato, provincias de Tucumán y Catamarca. Revista de la Asociación Geológica Argentina 63(1):24-28

48. Pilger R (1984) Cenozoic plate kinematics, subduction and magmatism South American Andes. J Geol Soc Lond 41:793-802

49. Strecker MR, Bloom AL, Malizzia D, Cerveny P, Bossi GE, Bensel $\mathrm{CH}$, Villanueva-García A (1987) Nuevos datos Neotectónicos sobre las Sierras Pampeanas Septentrionales $\left(26^{\circ}-27^{\circ} \mathrm{S}\right)$, República Argentina. Décimo Congreso Geológico Argentino, San Miguel de Tucumán 1:231-234

50. Löbens S, Sobel ER, Bense FA, Wemmer K, Dunkl I, Siegesmund $S$ (2013) Refined exhumation history of the northern Sierras 
Pampeanas, Argentina. Tectonics 32:453-472. https://doi.org/ 10.1002/tect.20038

51. INPRES (Instituto Nacional de Prevención Sísmica) (2018) Reglamento INPRES-CIRSOC 103, Reglamento Argentino para construcciones sismorresistentes, Parte I. Ministerio del Interior, Obras Públicas y Vivienda, Secretaría de Planificación Territorial y Coordinación de Obra Pública. 86 pp

52. IRIS (Incorporated Research Institutions for Seismology) (2020) 1200 New York Av. NW Suite 400, Washington, DC 20005, 202682-2220. http://ds.iris.edu/

53. Sibson RH (1982) Fault zone models, heat flow, and the depth distribution of earthquakes in the continental crust of the United States. Bull Seismol Soc Am 72:151-163

54. Sibson RH (1983) Continental fault structure and the shallow earthquake source. J Geol Soc Lond 140:741-761

55. Scholz CH (1988) The brittle/plastic transition and the depth of seismic faulting. Geol Rundsch 77:319-328

56. Scholz CH (2002) Mechanics of earthquakes and faulting, 2nd edn. Cambridge University Press, New York

57. Allen JL (2011) Shaw CA (2011) Seismogenic structure of a crystalline thrust fault: fabric anisotropy and coeval pseudotachylyte-mylonitic pseudotachylyte in the Grizzly Creek Shear Zone, Colorado. In: Fagereng A, Toy VG, Rowland JV (eds) Geology or the earthquake source: a volume in honour of Rick Sibson. Geological society, vol 359. Special Publications, London, pp 135-151

58. Brace W, Byerlee JD (1966) Stick-slip as a mechanism for earthquakes. Science 153:990-992

59. Fagereng A, Toy VG (2011) Geology of the earthquake source: an introduction. In: Fagereng A, Toy VG, Rowland JV (eds) Geology or the earthquake source: a volume in honour of Rick Sibson. Geological Society. London, Special Publications, pp 1-16

60. Nortje GS, Olive NHS, Blenkinsop TG, Keys DL, Mclellan JG (2011) Oxenburgh S (2011) New faults v fault reactivation: implications for fault cohesion, fluid flow and copper mineralization, Mount Gordon Fault Zone, Mount Isa District, Australia. In: Fagereng A, Toy VG, Rowland JV (eds) Geology or the earthquake source: a volume in honour of Rick Sibson. Geological Society, vol 359. Special Publications, London, pp 287-311

61. Costa CH (2019) La migración del frente de corrimiento neotectónico de las Sierras Pampeanas y su impronta morfológica. Revista de la Asociación Geológica Argentina 76(4):315-325

62. Ambraseys NN, Tchalenko JS (1969) The Dasht-e-Bayaz (Iran) earthquake of August 31, 1968: a field report. Bull Seismol Soc Am 59:1751-1792

63. Wells DL, Coppersmith KJ (1994) New empirical relationships among magnitude, rupture length, rupture width, rupture area, and surface displacement. Bull Seismol Soc Am 84:974-1002

64. Kanamori H, Anderson DL (1975) Theoretical basis of some empirical relations in seismology. Bull Seismol Soc Am 65:1073-1095

65. Hanks TC, Kanamori H (1979) A moment magnitude scale. J Geophys Res 84:2348-2350

66. Kamb B, Silver LT, Abrams MJ, Carter BA, Jordan TH, Minster JB (1971) Pattern of faulting and nature of fault movement in the San Fernando earthquake, in The San Fernando, California, Earthquake of February 9, 1971. U S Geol Surv Prof Pap 733:41-54

67. Ikeda $Y$ (1983) Thrust front migration and its mechanisms-evolution of intraplate thrust fault systems: Bulletin of the Geography Department. Univ Tokyo 15:125-159

68. Costa C (2000) Geomorphic signature of Quaternary deformation and strategies for regional mapping in Argentina. In: Proceedings world active faults symposium, $31^{\circ}$ international geological congress, CD-Rom, Brazil
69. Costa $\mathrm{CH}$, Ahumada EA, Gardini $\mathrm{CE}$, Vázquez FR, Diederix H (2014) Quaternary shortening at the orogenic front of the Central Andes of Argentina: the Las Peñas Thrust System. In: Sepúlveda SA, Giambiagi LB, Moreiras SM, Pinto L, Tunik M, Hoke GD, Farías M (eds) Geodynamic processes in the andes of Central Chile and Argentina. Geological society, vol 399. Special Publications, London, p 21

70. Costa CH, Ahumada EA, Owen LA, Vázquez FR, Johnson WJ, Halperin AD (2014) Subducción subhorizontal y potencial sismogénico de las Sierras Pampeanas: paleosismología del sistema de fallas de la sierra Chica en el valle de Calamuchita, Córdoba. Actas XIX Congreso Geológico Argentino, Simposio subducción subhorizontal en el segmento Andino $27^{\circ}-33^{\circ} \mathrm{S}$ : un enfoque multidisciplinario, S20-18, 2 pp

71. Gutiérrez AA, Alderete MC, Bortolotti P (1997) Geomorfología tectónica (neotectónica) en la sierra de La Candelaria, provincia de Salta. IV Simposio Argentino de teledetección, Resúmenes, San Juan, 9 pp

72. Aranda-Viana RG, Bianchi C, Aramayo A, Alvarado L, Arnous A, Hongn F, Strecker M (2017) Modelo de imágenes y fotogrametría de la escarpa occidental de la Sierra de la Candelaria con el uso de vehículo aéreo no tripulado. Actas XX Congreso Geológico Argentino, Tucumán 201, 15 pp

73. Arnous A, Landgraf A, Gutllemoteau J, Gutiérrez AA, ArandaViana RG, Strecker M (2017) Quaternary tectonic activity of the Candelaria fault, Santa Bárbara System, NW Argentina $\left(26^{\circ}\right.$ Lat., $65^{\circ}$ Long.): New insights from geomorphic mapping and electrical-resistivity prospecting. XX Congreso Geológico Argentino, Sesión Técnica 13, Geofísica, geofísica aplicada y paleomagnetismo, $2 \mathrm{pp}$

74. Arnous $A$, Zeckra M, Venerdini A, Aranda G, Strecker M, Alvarado P, Hongn F, Gutiérrez AA (2018) Neotectonic activity in the broken foreland of the NW Argentine Andes (Candelaria range, $-26^{\circ}$ Lat., $-65^{\circ}$ Long.): New Insights from seismic refraction tomography, electrical-resistivity survey, and geomorphic analysis. Geophysical Research Abstracts, vol 20. EGU2018-16297, EGU General Assembly

75. Arnous $A$, Zeckra M, Venerdini A, Alvarado P, Arrowsmith R, Guillemoteau J, Landgraf A, Gutiérrez AA, Strecker MR (2020) Neotectonic Activity in the Low-Strain Broken Foreland (Santa Bárbara System) of the North-Western Argentinean Andes $\left(26^{\circ} \mathrm{S}\right)$. Lithosphere, Article ID 8888588, 25 pp

76. Abascal LV (2005) Combined thin-skinned and thick-skinned deformation in the central Andean foreland of northwestern Argentina. J S Am Earth Sci 19:75-81

77. Figueroa-Villegas S, Escalante L, Hongn F, Strecker M (2017) Deformación tectónica Holocena en la transición entre las Sierras Pampeanas y Cordillera Oriental, valle de Cafayate $\left(26^{\circ} 00^{\prime}\right.$

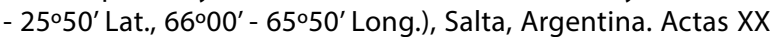
Congreso Geológico Argentino, Sesión Técnica 2, Geología estructural y geotectónica, 62-67

78. Bull WB (2007) Tectonic geomorphology of mountains: a new approach to paleoseismology. Blackwell, Malden

79. Woodcock NH, Fisher M (1986) Strike -slip duplexes. J Struct Geol 8(7):725-735

80. Cunningham WD, Mann $P$ (2007) Tectonics of strike-slip restraining and releasing bends. Geological Society Special Publication $\mathrm{N}^{\circ} 290$, London, 1-12

81. Rodgers D, Rizer WD (1981) Deformation and secondary faulting near the leading edge of a thrust fault, in Thrust and Nappe Tectonics, Geol. Soc. London, Spec. Pub., 9, 65-77

82. Mon R, Gutiérrez AA, Vergani G, Pacheco MM, Sábat F (2005) Estructura de la depresión tectónica de Metán (provincia de Salta). Actas del XVI Congreso Geológico Argentino, La Plata, 73-80 
83. Zampieri D, Gutiérrez AA, Massironi M, Mon R (2012) Reconciling opposite strike-slip kinematics in the transpressional belt of the Sierra Pampeanas (Argentina). European Geosciences Union General Assembly, Viena, Austria, 2 pp

Publisher's Note Springer Nature remains neutral with regard to jurisdictional claims in published maps and institutional affiliations. 